IFN Working Paper No. 941, 2012

\title{
Generosity and Political Preferences
}

Christopher T. Dawes, Magnus Johannesson, Erik Lindqvist, Peter Loewen, Robert Östling, Marianne Bonde and Frida Priks 


\title{
Generosity and Political Preferences
}

\author{
Christopher T. Dawes* Magnus Johannesson ${ }^{\dagger}$ Erik Lindqvist \\ Peter Loewen $^{\S}$ Robert Östling ${ }^{\llbracket}$ Marianne Bondell Frida Priks**
}

November 15, 2012

\begin{abstract}
We test whether generosity is related to political preferences and partisanship in Canada, Sweden, the United Kingdom and the United States using incentivized dictator games. The total sample consists of more than 5,000 respondents. We document that support for social spending and redistribution is positively correlated with generosity in all four countries. Further, we show that donors are more generous towards copartisans in all countries, and that this effect is stronger among supporters of left-wing political parties. All results are robust to the inclusion to an extensive set of control variables, including income and education.
\end{abstract}

*Department of Politics, New York University, 19 West 4th Street, 2nd Floor, NY, 10012. E-mail: cdawes@nyu.edu.

$\dagger$ Department of Economics, Stockholm School of Economics, P.O. Box 6501, SE-113 83 Stockholm, Sweden. E-mail: magnus.johannesson@hhs.se.

${ }^{\ddagger}$ Department of Economics, Stockholm School of Economics, P.O. Box 6501, SE-113 83 Stockholm, Sweden and Research Institute of Industrial Economics (IFN). E-mail: erik.lindqvist@hhs.se.

$\S$ Department of Political Science, University of Toronto-Mississauga, Mississauga, ON, Canada L5 L1C6. E-mail: peter.loewen@utoronto.ca.

『 Institute for International Economic Studies, Stockholm University, SE-106 91 Stockholm, Sweden. Email: robert.ostling@iies.su.se.

${ }$ No affiliation. Former student at the Stockholm School of Economics.

**No affiliation. Former student at the Stockholm School of Economics. 
Why are some people left-wing and others right-wing? One popular idea is that left-wing people are more other-regarding than right-wing people. The "bleeding hearts" of liberals and "heartless and cold" conservatives are typical stereotypes in U.S. politics (see e.g., Farwell \& Weiner 2000). In contrast, social scientists often focus on economic self-interest as the determinant of political preferences and most economic-political models assume that voters are self-interested. Yet the explanatory power of self-interest in empirical studies is usually quite low. ${ }^{1}$ This discrepancy between theoretical assumptions and empirical findings highlights the importance of finding other determinants of political preferences. ${ }^{2}$ For example, political preferences might be related to "deep" preference parameters that also determine choices in other domains, e.g. occupation.

In this paper, we focus on the relationship between social and political preferences. Specfically, we investigate whether generosity in the dictator game is related to political preferences and partisanship. ${ }^{3}$ Our focus on generosity is motivated by the fact the there are two distinct reasons to support social spending and redistribution. On the one hand, people might support social spending because they directly benefit from it. This "demand side-view" of social policy is the standard perspective in economic-political models. However, there are also reasons to consider the "supply side" of redistribution: voters might prefer high levels of spending and taxation because they want to help people they think deserve government support. This latter view suggests that preferences for social spending could be related to generosity. The difference between the "demand" and "supply side" view is important for a wide range of questions in political science, not least the sources of public opinion and policy

\footnotetext{
${ }^{1}$ See for instance the survey by Lewis-Beck \& Stegmaier (2007). There are also studies that confirm the view that self-interest affect political preferences, see Richter (2006), Elinder et al. (2008) and Manacorda et al. (2011) for some recent examples.

${ }^{2}$ The existing literature on the sources of political preferences ranges from behavioral genetic evidence (e.g. Alford et al. 2005, Benjamin et al. 2012), accounts rooted in early socialization (e.g. Green et al. 2002 , Johnston 2006), to accounts focusing on short-term influences (e.g. Zaller 1992, Page \& Jones 1979). Most closely related to this paper, there is a substantial literature suggesting that political preferences are related to personality (Mondak 2010, Mondak et al. 2010, Loewen et al. 2012, Hatemi \& McDermott 2011, Settle et al. 2009, Morton et al. 2011).

${ }^{3}$ In the dictator game (Forsythe et al. 1994), one participant (the dictator or donor) decides how to split a sum of money between herself and an another anonymous participant in the study. The receiver has no choice over the distribution.
} 
preferences, the basis of electoral competition, and the ideological positioning of political parties.

We carry out our study in four countries: Canada, Sweden, United Kingdom and the United States. The dictator game questions were incentivized in all countries and in Canada, Sweden and United Kingdom we use large, representative samples. In total our samples comprise more than 5,000 respondents. Although there are some design differences across our four country studies, the results are remarkably consistent.

Our first main finding is that generosity in the dictator game is positively related to political preferences for typical left-wing policies, in particular to preferences for spending on public goods. Except for the United Kingdom, the estimated coefficients become stronger when we control for a rich set of covariates, including income and education. The robustness of our results indicates that the relationship between generosity and support for public spending is not driven by omitted variables. Rather, our results support the view that people who support redistributive policies are fundamentally different in terms of "deep" preference parameters (Benjamin et al. 2012, Dawes et al. 2012). Respondents thus seem to be willing to give up private consumption in order to behave consistently with their political ideals, i.e. they "put their money where their mouth is". While our results do not rule out that self-interest also affects political preferences, the size of the estimated coefficients suggest that the "supply side" perspective is relevant for understanding redistributive policies.

For Canada and Sweden, the result that respondents with left-wing sympathies are more generous is confirmed when we consider support for political parties instead of particular policies. Supporters of the Democratic party are more generous than Republicans in the US sample, but the lower power in this sample implies that the effect is not statistically significant. However, in the UK, Tory supporters are more generous than those who support Labour, despite the fact that Labour supporters are more supportive of social spending. Dividing the sample by strength of partisanship, we find that the link between generosity and social spending is significantly stronger among non-partisans than partisans in the UK. 
We do not find a similar pattern in the other countries in our study. This result indicates that identification with political parties in the UK may be driven by factors related to generosity in a way that partly offsets the correlation between generosity and support for spending on public goods.

Our second main set of results relate to the in-group effect with respect to political partisanship first documented by Fowler \& Kam (2007). Asking donors to state how much they want to give to supporters of different political parties, we find that subjects are significantly less generous when donating money to someone that supports a different political party than their own. Interestingly, in all four countries, it is particularly supporters of left-wing parties that discriminate depending on the partisanship of the recipient.

The in-group effect shows either that voters care directly about other people's party preferences or that they take partisanship as a signal of deeper political values, preferences or personality traits that they care about. ${ }^{4}$ Regardless of which explanation is true, the existence of an in-group effect is likely to induce people to associate with others who share their political values (Eaves \& Hatemi 2008, Alford et al. 2011). For example, people might prefer to live in neighborhoods where many people vote for the same party, leading to political segregation in the housing market. ${ }^{5}$ Such "political assortative matching" among friends, colleagues, neighbors and mates is likely to exacerbate political polarization through two different mechanisms. First, a large literature has shown that people's political behavior is influenced by the friends, neighbors and peers they interact with. ${ }^{6}$ Second, in countries with majoritarian election systems, geographical segregation that makes constituencies more

\footnotetext{
${ }^{4}$ See Gerber et al. (2011) for a review about the literature on personality traits and political behavior. On a related note, there is a long-standing literature in social psychology demonstrating that similarity in attitudes more generally predicts altruistic behavior, attraction and friendship. See, for example, Batson et al. (1981), Byrne (1961), Byrne (1971), McGrath (1984) and Newcomb (1961).

${ }^{5}$ See Rodden $(2010)$ for an overview of the literature about geographical sorting along political lines.

${ }^{6}$ The literature on social interaction from person to person and political behavior includes, for example, Sheingold (1973), Tedin (1980), Weatherford (1982), Huckfeldt \& Sprague (1991) and Tam Cho et al. (2006). In a related vein, Madestam et al. (2011) use weather as an instrumental variable for the size of Tea Party rallies and show that large rallies caused an increase in turnout in favor of the Republicans in the 2010 Congressional elections. Another related literature studies social pressure and voter mobilization, see Eldersveld (1956), Gerber \& Green (2000), Gerber et al. (2008), Davenport et al. (2010), Gerber \& Green (2010), Mann (2010) and Bond et al. (2012).
} 
definitively left or right induces political candidates to position themselves away from the political centre. ${ }^{7}$

An effect of in-group favoritism on polarization could have consequences that go beyond the political system. For example, Gradstein \& Justman (2002) argue that polarization has a negative effect on national income because it increases transaction costs. Relatedly, Lindqvist \& Östling (2010) show that political polarization is strongly negatively correlated with economic performance.

The finding that the in-group effect is strongest among left-wing donors opens the door to an interesting theoretical possibility: some people may exhibit stronger support for social spending when other voters are more supportive of higher spending, implying that a shift to the left in the political preferences of an electorate may be self-reinforcing. Such a complementarity between political preferences could give rise to multiple voting equilibria. ${ }^{8}$

The dictator game has been replicated numerous times and studies have consistently shown that subjects donate non-negligible amounts (see e.g. Camerer 2003, List 2007). The typical finding is that a majority of subjects either keep everything or give away exactly half of the money (see e.g. Engel 2011). Andreoni \& Bernheim (2009) argue that such a distribution of responses is most easily explained by adherence to a norm to share the money exactly equally combined with social image concerns. One interpretation of our findings is therefore that the 50-50 sharing norm is stronger among people who support redistribution and social spending. In other words, support for an underlying sharing norm might be reflected both in dictator game generosity and support for "generous" government policies.

Most previous dictator game experiments have been done with university students and are therefore not representative of the general population (see Levitt \& List 2007). University subjects constitute a selected sample of the population and they are typically also selfselected into participating in experiments. We address this critique by including the dictator

\footnotetext{
7 Austen-Smith (1984) and Callender (2005) show theoretically that policy platforms diverge more the more heterogeneous are preferences across districts.

${ }^{8}$ See Shayo (2009) and Lindqvist \& Östling (2011) for related theoretical models that show how in-group effects might give rise to multiple political equilibria.
} 
games in large national surveys in Canada, the UK and Sweden. However, we also report the results from a laboratory experiment in the US which uses a convenience sample of university students. In addition, we briefly discuss the results from a pilot experiment in Sweden which was conducted with public high school students who took part in the experiment as a part of their regular teaching.

We are not aware of any previous studies that relate preferences for redistribution and social spending to social preferences measured by the dictator game or related games..$^{9}$ There are a few studies, however, that have studied the relationship between social preferences and political partisanship. Studies with US (student) subjects have not found an effect of partisanship on generosity in dictator games (Fowler 2006, Fowler \& Kam 2007) or behavior in ultimatum, trust and public goods games (Alford \& Hibbing 2007, Anderson et al. 2005). Fowler \& Kam (2007) document that donors, and in particular Democrat donors, are more generous toward recipients who support the same party. We show that the political in-group effect holds also in representative samples in three additional countries (Canada, Sweden and the UK). In addition, we show that the in-group effect is consistently stronger among left-leaning partisans.

We are aware of two European studies focusing on the relationship between partisanship and pro-social preferences in large national survey samples. Both studies find a systematic relationship between partisanship and pro-social preferences. Damgaard (2008) finds that left-wing respondents in Denmark contribute less in public goods games. Fehr et al. (2003) report results from a trust game with a representative sample of Germans. They find that Social Democrats and Christian Democrats are more trusting and that Christian Democrats are less trustworthy.

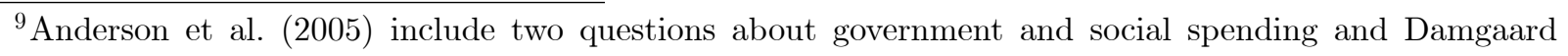
(2008) includes a question about government responsibility in their surveys, but they do not report the correlation with behavior in the experimental games they study.
} 


\section{$1 \quad$ Study Design}

In Canada, UK and Sweden, the dictator games were included in surveys conducted by commercial public opinion research firms. In the US study, the dictator games were instead incorporated into a laboratory experiment. In addition, we briefly report the results from a Swedish pilot study that was conducted as a classroom experiment in upper secondary schools in Stockholm. The details about this pilot experiment are relegated to the Appendix. In this section we describe the design of the four main country studies.

\section{$1.1 \quad$ Subjects}

The Canadian, Swedish and UK studies were conducted as online surveys. The aim of the surveys was to obtain a representative sample of the general population. Yet it is clear that online surveys cannot be fully representative (e.g. due to non-universal Internet access and attendant sampling problems). The Canadian survey was conducted in May 2007 and consisted of 5,399 respondents. Respondents in the second half of May (2,771 in total) were also administered questions about willingness-to-pay for public goods. ${ }^{10}$ The UK survey was conducted in six waves from December 2009 to January 2010 with a total of 1,462 respondents. The Swedish survey was conducted in May 2011 and included 1,036 respondents.

The US study was conducted as a part of a computerized laboratory experiment at the University of California-San Diego between November 2010 and March 2011. 262 students participated in the experiment. The advantage of laboratory experiments is that they provide a higher degree of control. The obvious drawback is that a sample of students at a prestigious university is not representative of the general US population. The results from the US study should therefore be interpreted with caution.

\footnotetext{
${ }^{10}$ Respondents were randomized into participating in the first and second half of the study. Furthermore, the $R^{2}$ is 0.01 when regressing an indicator variable for whether we observe answers to the willingness-to-pay questions on our full set of control variables. Non-response is also uncorrelated with generosity in the dictator game.
} 
In order to provide a better view of the representativeness of the participants in the four studies, Table A1 in the Appendix compares the sample averages of some covariates to the population-wide averages in the four countries. Respondents in the online surveys are representative with respect to gender, but are 8 to 10 years older, better educated and have higher earnings than the population averages. Since our samples do not appear to be fully representative, we analyze in Section 3 whether the relationship between generosity and political preferences interact with age, gender, income or education. With Canada as one possible exception, we generally find little evidence of this. The non-representativeness of our survey samples are therefore unlikely to bias our empirical estimates.

\subsection{Survey Questions}

All four country studies include incentivized dictator games (to be described below) as well as a battery of questions about ideology, party identification, opinions about specific political proposals and basic demographics. ${ }^{11}$ The ordering and exact wording of the questions used in the paper are available in the Appendix.

In the UK, Swedish and US studies, we included a question asking respondents to place themselves on a left-right scale (from 1 to 10 in Sweden and the US and from 0 to 10 in the UK). In the Swedish case it was explicitly mentioned which political parties are usually considered to belong to the right and left. ${ }^{12}$ The US study also included a question taken from the World Values Survey which asked respondents to place their views on a 1 to 10 scale from "Incomes should be made more equal" to "We need larger income differences as incentives for individual effort". In the US and Swedish study, we included a question (again taken from the World Values Survey) which asked respondents to place their views on a ten-point scale ranging from "The government should take more responsibility to ensure

\footnotetext{
${ }^{11}$ The Canadian, UK and US surveys also include a number of questions not used in this paper.

${ }^{12}$ There is clear distinction between left-wing and right-wing parties in Sweden, with the exception of an anti-immigration party ("Sverigedemokraterna"). Consequently, 95 percent of respondents who were classified as left-wing based on the ideology question identified with a left-wing political party and 96 percent of those who were classified as right-wing identified with a right-wing party (excluding the anti-immigration party).
} 
that everyone is provided for" to "People should take more responsibility to provide for themselves". In the US study we also asked respondents to trade-off higher taxes against more spending on health and social services while in the UK respondents were simply asked whether taxes should be increased or cut.

In addition, we included a number of questions about willingness-to-pay (WTP) for public goods and publicly provided private goods. The format of these questions varied slightly between studies (see the Appendix for details). For example, Swedish respondents were asked sequentially if they would be willing to pay a particular amount. The WTP questions were not designed to obtain meaningful absolute valuations - the purpose was only to obtain a measure of the within-country relative valuations of respondents. The first WTP question (used in all but the UK study) asked respondents whether they would support carbon taxes if they knew that it would increase their energy-related expenditure by some stated amount per year. The second question asked respondents how much they would be willing to pay per year in higher taxes to cut waiting times in medical care. The third question concerned how much more respondents would be willing to pay in taxes to abolish tuition fees for university education. Since there are no tuition fees in Sweden, we instead included a question about whether respondents wanted to introduce tuition fees and, if so, how high they should be.

The wording of the party identification questions varies slightly between countries, but we aimed to stay close to the wording used in the American National Election Studies. For example, in Canada the wording is: "Thinking about federal politics in Canada, generally speaking, do you usually think of yourself as Liberal, Conservative, N.D.P. or none of these?" In the other countries, we restrict attention to the Conservative, Labour and Liberal Democrat parties in the UK, the Republican and Democratic parties in the US, and the eight political parties in the Swedish parliament. The party identification question was immediately followed by a question about the strength of partisanship (on a scale that differed slightly across countries). 
All four studies included a number of questions about demographic background characteristics which are included as control variables in the regressions. Details about the included control variables can be found at the bottom of Table 1 . The exact wording of the survey questions used for each country can be found in Table A2 to A5 in the Appendix.

\subsection{Dictator Game Design}

In the dictator game, respondents who are given the role of "dictator" are asked to allocate a fixed monetary endowment between themselves and a recipient. The optimal strategy for a completely selfish dictator is to keep the entire endowment for herself, yet a large body of research has shown that a non-trivial fraction of dictators donate positive amounts.

All four country studies included an incentivized dictator game question where the respondent split a sum of money between herself and another anonymous respondent in the survey. Respondents in Canada and the UK were also asked how much they would be willing to give to a respondent identifying with one of the three major political parties in respective country. The order of the dictator game questions were randomized for each respondent.

In the Swedish survey, respondents were first asked how much they would donate to anonymous recipient. Respondents were then asked how much they would donate to a "leftwing" or "right-wing" respondent. We randomized the order of these questions. Finally, respondents were asked to state how much they would like to someone supporting the largest right-wing party ("Moderaterna") and to someone supporting the largest left-wing party ("Socialdemokraterna"). The order of these two questions was again randomized.

The US experiment also began by asking respondents to state their donations to an anonymous participant in the experiment. Thereafter, half of the respondents were asked how much they would donate to a Republican participant and the other half how much they would donate to a "conservative" participant. Finally, half of the respondents were asked how much they would donate to a Democrat participant and the other half how much they 
would donate to a "liberal" participant. ${ }^{13}$

The size of the endowment in the dictator games varied slightly between the four studies. In the Canadian survey, each dictator game question asked respondents to split a prize of 100 Canadian dollars between herself and another participant in the survey. Respondents could choose any amount between 0 and 100 dollars. For each question, one randomly selected dictator-recipient pair received a 100 dollar prize that was shared between them according to the dictator's decision. In the UK study, respondents were asked in each question to allocate 10,000 points which corresponded to prizes of 100 GBP each. As for the Canadian study, one allocation was randomly selected for each type of dictator-recipient pair. In the Swedish study, subjects allocated 1000 SEK in each dictator game. They were told that for each of the five questions the allocations of two dictators would be randomly chosen and paid out to the dictators and recipients. In the US study, three prizes of 100 USD were drawn corresponding to each of the three dictator game questions. The total amounts paid out in the studies were consequently 400 Canadian dollars (four prizes of 100 dollars each), 400 GBP (four prizes of 100 GBP each), 10,000 SEK (ten prizes of 1000 SEK) and 300 USD (three 100 dollar prizes), approximately corresponding to 400, 650, 1500 and 300 USD. On average respondents were paid between 7 cents (in the Canadian study) to 1.4 dollars (in the Swedish study). While the stakes involved are quite low, previous studies have found that stakes matter relatively little in dictator games (see e.g. Engel 2011).

In the remainder of the paper, decisions by dictators will be measured as the percentage share of the maximal contribution.

\section{Estimation}

We first investigate whether ideology (on the left-right scale), preferences for social spending and willingness to pay (WTP) for public goods are related to generosity in the dictator game.

\footnotetext{
${ }^{13}$ Respondents were randomly assigned to either receiving information about the ideology (conservative/liberal) or party affiliation (Republican/Democrat) at each step, implying that approximately 1/4 of the participants acted as dictators towards both a Republican and a Democrat recipient.
} 
Let $D O N A T E_{i}$ denote the donation of respondent $i$ to a completely anonymous recipient, $x_{i}$ her response to some question about political preferences and let $\mathbf{Z}_{i}$ be a vector of control variables. $\mathbf{Z}_{i}$ includes income, education, gender, age as well as some additional variables that vary from country to country (see the bottom of Table 1 for details). We estimate the following regression equation (using OLS) for each country separately:

$$
D O N A T E_{i}=\alpha+\beta_{1} x_{i}+\boldsymbol{Z}_{i} \boldsymbol{\delta}_{j}+\varepsilon_{i}
$$

The coefficient $\beta_{1}$ is our estimate of the strength of the relationship between generosity and political preferences. We keep the scaling of $x_{i}$ implied by each question, except in one case where we reverse the scale for Sweden in order to make the results comparable to the other countries. The sign of $\beta_{1}$ is thus directly comparable between countries for a particular question, but not across questions as it depends on whether high values of $x_{i}$ indicate "left-wing" or "right-wing" political values. We scale the WTP questions so that they are roughly comparable across countries. WTP is measured in 1,000 dollars in the US and Canada, 10,000 SEK in Sweden and strength of approval controlling for the proposed sum in the UK. For the questions about WTP for public goods, $\beta_{1}>0$ implies that people with a high willingness to pay are more generous in the dictator game.

In order to study the relationship between partisanship and generosity, we again focus on the donation to a completely anonymous recipient. Let $P A R T Y n_{i}$ be an indicator variable for whether respondent $i$ identifies with party $n$. In Sweden we only distinguish between whether a respondent identifies with a party in the left-wing or right-wing bloc. The reason is that there are eight political parties in the Swedish parliament, seven of which clearly belong to either bloc (we ignore the anti-immigration party). For the countries with three major parties (Canada and the UK) we estimate the following regression:

$$
D O N A T E_{i}=\alpha+\beta_{1} P A R T Y 1_{i}+\beta_{2} P A R T Y 2_{i}+\boldsymbol{Z}_{i} \boldsymbol{\delta}+\varepsilon_{i}
$$


whereas the regression only includes $P A R T Y 1_{i}$ for Sweden and the US. The coefficients $\beta_{1}$ and $\beta_{2}$ indicate the difference in average donations between the respondents who identify with the party in question and those who identify with the baseline party excluded from the regression.

To test whether there is an in-group effect in the dictator game, we regress dictator $i$ 's donation to recipient $j$ with known partisanship. The number of decisions per respondent in this regression depends on the number of political parties: two for the US and Sweden and three for Canada and the UK. We estimate the following regression model:

$$
D O N A T E_{i j}=\alpha+\beta_{1} P A R T Y 1_{i}+\beta_{2} P A R T Y 2_{i}+\gamma S A M E_{i j}+\boldsymbol{Z}_{i} \boldsymbol{\delta}+\varepsilon_{i j}
$$

where $P A R T Y 2_{i}$ is only included for Canada and the UK, and $S A M E_{i j}$ is an indicator variable equal to one in case dictator $i$ and recipient $j$ identify with the same party. $\gamma>0$ indicates that there is a partisan in-group effect. In this and the following specification, we cluster standard errors at the level of the individual since we now include two or three decisions for each respondent.

Finally, to test whether the in-group effect is equally strong among left-wing and rightwing donors, we estimate the following equation:

$$
\begin{aligned}
D O N A T E_{i j}= & \alpha+\beta_{1} P A R T Y 1_{i}+\beta_{2} P A R T Y 2_{i}+\gamma S A M E_{i j} \\
& +\eta_{1} P A R T Y 1_{i} \times S A M E_{i j}+\eta_{2} P A R T Y 2_{i} \times S A M E_{i j}+\boldsymbol{Z}_{i} \boldsymbol{\delta}+\varepsilon_{i} .
\end{aligned}
$$

The coefficients $\eta_{1}$ and $\eta_{2}$ show how much more or less supporters of party 1 and 2 donate to supporters of their own party compared to recipients from the baseline party. Note that $P A R T Y 2_{i}$ and its interaction term are excluded in regression (3) and (4) for Sweden and the US. 


\section{Results}

Figure 1 shows histograms for donations to completely anonymous recipients. Mean donations in terms of the maximum amount were 22.4 percent in Canada, 42.2 percent in Sweden, 15.5 percent in the UK and 18.6 percent in the US. ${ }^{14}$ Except for Sweden, the mode is a zero donation, followed by an equal split. Very few respondents give away more than 50 percent. These patterns are well in line with previous dictator game studies (see the meta study by Engel 2011), although the respondents in our Swedish sample stand out as being generous. ${ }^{15}$

Figure 1. Donations to Anonymous Recipients
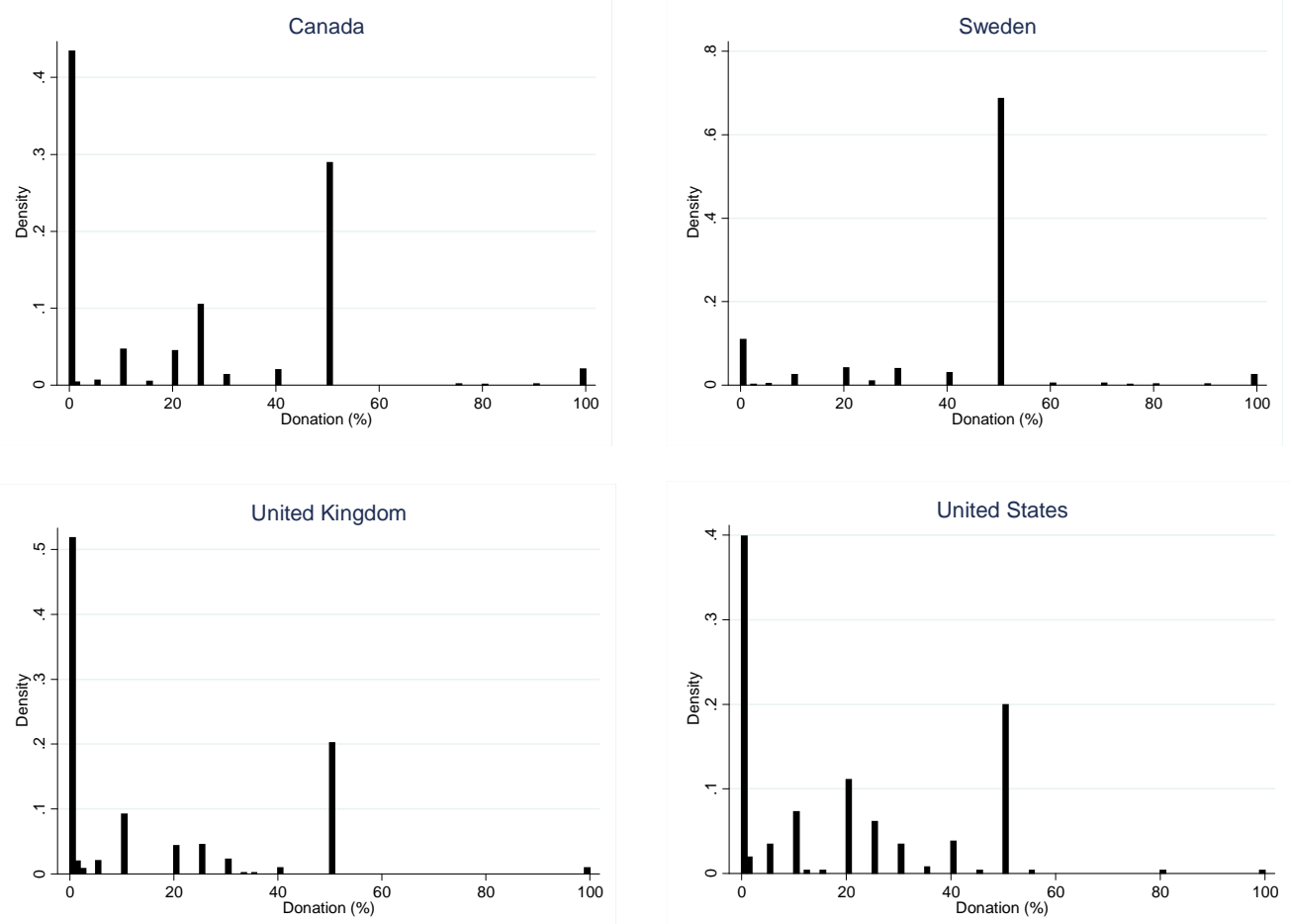

Table 1 shows the estimate of $\beta_{1}$ and its standard errors for all political preference questions using regression (1). Note that Table 1 does not report the coefficients for the

\footnotetext{
${ }^{14}$ The figure for Canada refers to the subsample for which we observe WTP for at least one type of public good.

${ }^{15}$ We are only aware of one Swedish dictator game study based on a representative sample. Preliminary and unpublished results from that study are in line with our finding - more than 50 percent donated half the amount.
} 
covariates. The first column for each country in Table 1 reports the results when no control variables are included in the regression. The second column shows the result without control variables for respondents with non-missing values for all control variables. The third column reports the estimated coefficient with control variables. A high value of the dependent variable indicates agreement with the statement shown to the left in Table 1.

As shown in Table 1, generosity in the dictator game is negatively associated with rightist ideology in Sweden, the UK and the US (the question was not available for Canada). The estimated coefficients imply that moving from 1 to 10 on the left-right scale is associated with an increase in the donated share by 3 (UK) to 16 percentage points (US). The pattern and magnitude of the coefficients are the same also for the questions regarding taxes and income inequality, but weaker for the question about government responsibility. The estimated coefficients are not always statistically significant, but all coefficients indicate a positive relationship between generosity and leftist political values. Except for the UK, the estimated effects are generally strengthened when control variables are added to the regression.

\section{[TABLE 1 ABOUT HERE]}

Willingness-to-pay for public goods (and publicly provided private goods) is also positively related to generosity in all countries. In all but one case is the estimated relationship between WTP and generosity stronger when control variables - including income - are included in the regressions. This suggests that the relationship between generosity and WTP is not due to a correlation between generosity and socio-economic factors, such as income and education. The strength of the estimated relationship between WTP and generosity is also non-trivial. For example, in Canada an increase in WTP for medical care by 1,000 Canadian dollars predicts an increase in the donated share by 3.7 to 4.1 percentage points. We conclude from Table 1 that political preferences are related to generosity in the dictator game.

Table 2 presents the results regarding generosity and partisanship. For each country, the left column shows the results for all partisans while the right column shows the result 
when we restrict the sample to respondents who identify strongly with a political party. All regressions reported in Table 2 include the set of covariates. The first panel in Table 2 shows the estimated coefficients from regression (2). We find that left-wing partisans are more generous than right-wing partisans in Canada and Sweden. In the US, Republicans are less generous than Democrats, but the effect is not statistically significant. Somewhat surprisingly, supporters of Tories and Liberal Democrats in the UK are more generous than supporters of Labour (we discuss the case of the UK separately below). With one exception (Liberal democrats in the UK), the results do not change appreciably when we restrict the sample to strong partisans.

\section{[TABLE 2 ABOUT HERE]}

The second panel of Table 2 shows the results from regression (3) that serve to test for an in-group effect with respect to partisanship. The in-group effect is positive and statistically significant in all countries (although less so in the US). The magnitude is nontrivial: dictators donate 5 to 10 percentage points less of their total endowment when faced with a recipient with a different political view.

The third panel shows that the in-group effect is primarily driven by supporters of leftwing political parties. The interaction effect with respect to right-wing parties is negative in all countries and significantly so in Canada, Sweden and the UK. For example, leftwing partisans in Sweden donate 15 percentage points more to left-wing than to rightwing recipients, whereas right-wing partisans only donate 6 percentage points more to rightwing compared to left-wing recipients. ${ }^{16}$ The results are very similar for the sub-sample of participants that identify strongly with a political party, with the US as a possible exception (but in this case most estimated coefficients are not statistically indistinguishable from zero

\footnotetext{
${ }^{16}$ We have also re-estimated regression (2)-(4) for Sweden using partisanship with respect to one of the two major parties in Sweden (the Social Democrats and the Moderates). The results confirm the results for regression (3) and (4) in Table 2. Respondents are more generous toward co-partisans and the effect is stronger for supporters of the Social Democratic party (the major party of the left-wing bloc in Sweden). However, Social Democrats are not more generous to anonymous recipiens in regression (2). These results are available upon request.
} 
anyway due to a considerably smaller sample size). The results with respect to in-group effects in regression (3) and (4) are very similar when we control for respondent fixed effects, thereby only using variation in allocations to different recipients within respondents (results available upon request). ${ }^{17}$

We conclude from Table 2 that there is an in-group effect in all countries and that it seems to be primarily driven by supporters of left-wing parties. But are the participants aware of their own in-group behavior? One way to investigate this is to test to what extent the in-group effect interacts with the ordering of choices. When asked the first question about a partisan recipient, dictators did not know what type of recipient would show up in the next question. In the Swedish survey, we randomized whether respondents should face a left-wing or right-wing recipient after they made the first allocation to an anonymous recipient. Half of the subjects were thus asked how much to donate to a left-wing recipient and the other half to a right-wing recipient. This structure of the Swedish survey enables us to re-estimate regression (3) interacing $S A M E_{i j}$ with an indicator variable equal to one for the first dictator game with a partisan recipient. As shown in Table A6, the interaction effect is positive and statistically significant at the 10 percent level, implying that the ingroup effect is weaker in the second partisan dictator game. This suggests that dictators are aware of their own discriminating behavior when they are faced with the second decision and that they respond by discriminating less, presumably because they want to adhere to norms against discrimination.

We have also investigated whether the estimated coefficients from regression (1)-(4) vary across sub-groups. For Canada, the UK and Sweden, we interacted our independent variables of interest with indicator variables for, in turn, below median values for age, income and education, and gender. We run one regression for each type of interaction effect. In general,

\footnotetext{
${ }^{17}$ The only exception is the results for the US. However, due to the setup in this experiment where the type of information about recipient partisanship (ideology or party affiliation) was randomized to respondents, there are only 47 observations for which we observe allocations to both in-group and out-group recipients (defined according to party affilitiation), implying that estimation becomes highly imprecise when we control for respondent fixed effects.
} 
the associations in the data documented in Table 1 and 2 do not interact with socioeconomic characteristics. There are two exceptions to this rule. First, in Canada the relationship between generosity and willingness to pay for public goods is stronger among young and male respondents. ${ }^{18}$ Second, the in-group effect appears to be weaker for younger respondents in Sweden and Canada. ${ }^{19}$ These results are available upon request.

\subsection{The Case of UK}

As discussed above, support for left-wing political parties is strongly positively related to generosity in Canada and Sweden and possibly also in the US. What stands out is that conservative partisans are more generous than Labour supporters in the UK. One potential explanation is that conservatives in the UK do not have the same right-wing political preferences as in the other countries. To investigate this hypothesis, Table 3 shows the relationship between partisanship and the survey questions about political preferences from Table 1 . The dependent variables in Table 3 are the response to the political preference questions and the independent variables are indicator variables for the preferred party and the same control variables as in Table 1 and 2.

\section{[TABLE 3 ABOUT HERE]}

As shown in Table 3, right-wing partisanship is related to typical right-wing policies in all four countries, including the UK. However, despite the systematic relationship between partisanship and political preferences on the one hand, and between political preferences and generosity on the other, conservatives in the UK are more generous than left-wing party supporters. This suggests either that there is an omitted variable that is correlated

\footnotetext{
${ }^{18}$ The interaction effect between WTP and age is statistically significant in all three WTP questions, while the interaction effect between WTP and gender is significant is significant for WTP for climate change and medical care, but not for tuition fees.

${ }^{19}$ As expected given the large number of hypotheses tested in these regressions, there are a few additional instances of statistically significant interaction effects. However, there are no systematic patterns across countries or questions except for the two cases discussed above. Given the relatively small number of participants in the US experiment, we do not consider it worthwhile to look for heterogeneous effects in this sample.
} 
with both partisanship and generosity in the UK, or that people who identify with a party are different from non-partisans. We test whether there is a difference in the relationship between political preferences and generosity by estimating the regressions in Table 4 for partisans and non-partisans separately. As shown in Table 4, the results are very similar for partisans and non-partisans in all countries but the UK where willingness to pay for public goods is uncorrelated with generosity among partisans. It thus appears to be something about partisans in the UK which implies that political preferences are not correlated with generosity in this particular group.

\section{[TABLE 4 ABOUT HERE]}

\subsection{Swedish Pilot Study}

Before carrying out the Swedish survey study, we conducted a laboratory experiment with high school students in Sweden. Although the pilot sample is not representative of the general population, participants are not self-selected into participating (participation was mandatory) and the stakes are considerably larger than in the other country studies. Detailed results from this pilot experiment are presented in Appendix and summarized briefly here.

The pilot study included one dictator game per respondent. In this game, the political partisanship of the recipient was known to the dictator, implying that we can estimate specification (3) and (4) but not (1) and (2) where the recipient was completely anonymous.

The results from the pilot study confirm the strong relationship between left-wing partisanship and generosity found in the Swedish survey study. Right-wing donors donate about 50 percent less on average than left-wing donors. In contrast, we found only weak evidence of an in-group effect.

While there is no obvious explanation as to why the in-group effect is weaker in the pilot study, a potential explanation lies in the design of the experiment. In the pilot, the respondents were told that the recipients were students in another class room. To the extent that students already think of students in other classes as an "outgroup", the political views 
of the recipients may play a smaller role. In the final Swedish survey study we avoid this ambiguity since the political partisanship is the only information respondents have about the recipients.

\section{Conclusion}

We have shown that there is a positive relationship between generosity in the dictator game and support for social spending, the provision of public goods and income redistribution. With the UK as a notable exception, there is also a relationship between left-wing partisanship and generosity. In addition, we have shown that generosity is contingent on the political party preference of the recipient - in particular left-wing donors tend to give more to recipients who share their political views.

Our results thus indicate that people who behave generously towards others also support generosity on the part of the government and are more likely to align with parties on the left of the political spectrum. This suggests that political competition - in our case in four rather different countries - sorts individuals into political parties according basic preferences.

While we cannot rule out self-interest as a determinant of political preferences, our results do suggest that it is a relatively restrictive assumption. The assumption of purely selfinterested voters in theoretical models should therefore be made with caution. For example, voter turnout is hard to explain if voters are self-interested and rational, but can easily be resolved if voters are assumed to be altruistic (e.g. Edlin et al. 2007, Loewen 2011). ${ }^{20}$ Furthermore, a link between political values and generosity suggests that the correlation between economic status and support for redistribution may not only reflect self-interest. For example, if preferences for redistribution are determined by generosity and generosity also determines the propensity to choose a low-paid occupation, then low income might be spuriously related to preferences for redistribution.

\footnotetext{
${ }^{20}$ Fowler (2006) shows that altruism (as measured by dictator game giving) is indeed positively related to voter turnout.
} 
A methodological challenge in measuring generosity is that behavior in the dictator game could be affected by social image concerns (as highlighted by Andreoni \& Bernheim 2009). An alternative interpretation of our findings is therefore that leftist subjects are more concerned about social image. We find this view less convincing, partly because participants in our experiments are anonymous, but it might nevertheless be interesting to disentangle the two possible explanations in future research.

Another challenge is to understand why political preferences and generosity are correlated. For example, can generosity can be viewed as a determinant of political preferences in the sense that people form their political views based upon a set of (more or less) fixed basic preferences to which generosity belongs? A potential avenue for exploring this question is to measure generosity early in life and then link this information to generosity and political views in adulthood. Relatedly, a growing body of work in the behavior genetics of politics suggests that both social and political preferences are heritable Alford et al. 2005, Cesarini et al. 2009), raising the question of whether they share the same underlying genetic structure.

\section{References}

Alford, J., Hatemi, P., Hibbing, J., Martin, N. \& Eaves, L. (2011), 'The politics of mate choice', Journal of Politics 73(02), 362-379.

Alford, J. R., Funk, C. L. \& Hibbing, J. R. (2005), 'Are political orientations genetically transmitted?', American Political Science Review 99(2), 153-167.

Alford, J. R. \& Hibbing, J. (2007), 'Personal, interpersonal, and political temperaments', ANNALS of the American Academy of Political and Social Science 614(1), 192-212.

Anderson, L. R., Mellor, J. M. \& Milyo, J. (2005), 'Do liberals play nice? The effects 
of party and political ideology in public goods and trust games', Advances in Applied Microeconomics 13(1), 107-131.

Andreoni, J. \& Bernheim, B. D. (2009), 'Social image and the 50-50 norm: A theoretical and experimental analysis of audience effects', Econometrica 77(5), 1607-1636.

Austen-Smith, D. (1984), 'Two-party competition with many constituencies', Mathematical Social Sciences 7(2), 177-198.

Batson, C. D., Duncan, B. D., Ackerman, P., Buckley, T. \& Birch, K. (1981), 'Is empathic emotion a source of altruistic motivation?', Journal of Personality and Social Psychology 40(2), 290-302.

Benjamin, D., Cesarini, D., van der Loos, M., Dawes, C., Koellinger, P., Magnusson, P., Chabris, C., Conley, D., Laibson, D., Johannesson, M. \& Visscher, P. M. (2012), 'The genetic architecture of economic and political preferences', Proceedings of the National Academy of Sciences 109(21), 8026-8031.

Bond, R. M., Fariss, C. J., Jones, J. J., Kramer, A. D., Marlow, C., Settle, J. E. \& Fowler, J. H. (2012), 'A 61-million-person experiment in social influence and political mobilization', Nature 489(1), 295-298.

Byrne, D. (1961), 'Interpersonal attraction and attitude similarity', Journal of Abnormal Social Psychology 62(1), 713-715.

Byrne, D. (1971), The Attraction Paradigm, Free Press, New York.

Callender, S. (2005), 'Electoral competition in heterogeneous districts', Journal of Political Economy 113(5), 1116-1145.

Camerer, C. (2003), Behavioral Game Theory: Experiments in Strategic Interaction, Princeton University Press. 
Cesarini, D., Dawes, C., Johannesson, M., Lichtenstein, P. \& Wallace, B. (2009), 'Genetic variation in preferences for giving and risk taking', Quarterly Journal of Economics $\mathbf{1 2 4}(2), 809-842$.

Damgaard, M. (2008), Do left wingers put their money where their mouth is? Working Paper, Copenhagen University.

Davenport, t. C., Gerber, A. S., Green, D. P., Larimer, C. W., Mann, c. B. \& Panagopoulos, C. (2010), 'The enduring effects of social pressure: Tracking campaign experiments over a series of elections', Journal of Political Behavior 32(1), 423-430.

Dawes, C. T., Loewen, P. J., Schreiber, D., Simmons, A. N., Flagan, T., McElreath, R., Bokemper, S. E., Fowler, J. H. \& Paulus, M. P. (2012), 'Neural basis of egalitarian behavior', Proceedings of the National Academy of Scieneces of the United States of America $\mathbf{1 0 9}(17), 6479-6483$.

Eaves, L. \& Hatemi, P. (2008), 'Transmission of attitudes toward abortion and gay rights: Effects of genes, social learning and mate selection', Behavior Genetics 38(3), 247-256.

Edlin, A., Gelman, A. \& Kaplan, N. (2007), 'Voting as a rational choice: Why and how people improve the well-being of others"', Rationality and Society 19(3), 293-314.

Eldersveld, S. J. (1956), 'Experimental propaganda techniques and voting behavior', American Political Science Review 50(1), 154-165.

Elinder, M., Jordahl, H. \& Poutvaara, P. (2008), Selfish and prospective: Theory and evidence of pocketbook voting. CESifo Working Paper Series No. 2489.

Engel, C. (2011), 'Dictator games: a meta study', Experimental Economics 14(4), 583-611.

Farwell, L. \& Weiner, B. (2000), 'Bleeding hearts and the heartless: Popular perceptions of liberal and conservative ideologies', Personality and Social Psychology Bulletin 26(7), 845852. 
Fehr, E., Fischbacher, U., von Rosenbladt, B., Schupp, J. \& Wagner, G. G. (2003), A nation-wide laboratory: Examining trust and trustworthiness by integrating behavioral experiments into representative survey. CesIfo Working Paper No 866.

Forsythe, R., Horowitz, J., Savin, N. \& Sefton, M. (1994), 'Fairness in simple bargaining experiments', Games and Economic Behavior 6(3), 347-369.

Fowler, J. (2006), 'Altruism and turnout', Journal of Politics 68(3), 674-683.

Fowler, J. H. \& Kam, C. (2007), 'Beyond the self: Altruism, social identity, and political participation.', Journal of Politics 69, 813-827.

Gerber, A. S. \& Green, D. P. (2000), 'The effects of canvassing, telephone calls and direct mail on voter turnout: A field experiment', American Political Science Review 94(3), 653-663.

Gerber, A. S. \& Green, D. P. (2010), 'Introduction to social pressure and voting: New experimental evidence', Journal of Political Behavior 32(1), 331-336.

Gerber, A. S., Green, D. P. \& Larimer, C. W. (2008), 'Social pressure and voter turnout: Evidence from a large-scale field experiment', American Political Science Review 102(1), 3348.

Gerber, A. S., Huber, G. A., Doherty, D. \& Dowling, C. M. (2011), 'The big five personality traits in the political arena', Annual Review of Political Science 14(1), 265-287.

Gradstein, M. \& Justman, M. (2002), 'Education, social cohesion and economic growth', American Economic Review 92(4), 1192-1204.

Green, D. P., Palmquist, B. \& Schickler, E. (2002), Partisan Hearts and Minds: Political Parties and the Social Identities of Voters, Yale University Press, New Haven.

Hatemi, P. K. \& McDermott, R. (2011), Man is by nature a political animal: evolution, biology, and politics, University of Chicago Press, Chicago. 
Huckfeldt, R. \& Sprague, J. (1991), 'Discussant effects on vote choice: Intimacy, structure, and interdependence', Journal of Politics 53(1), 122-158.

Johnston, R. (2006), 'Party identification: Unmoved mover or sum of preferences?', Annual Review of Political Science 9, 329-351.

Levitt, S. D. \& List, J. A. (2007), 'What do laboratory experiments measuring social preferences reveal about the real world?', Journal of Economic Perspectives 21(2), 153-174.

Lewis-Beck, M. \& Stegmaier, M. (2007), Economic models of voting, in R. Dalton \& H.-D. Klingemann, eds, 'Oxford Handbook of Political Bahavior', Oxford University Press.

Lindqvist, E. \& Östling, R. (2010), 'Political polarization and the size of government', American Political Science Review 104(3), 543-565.

Lindqvist, E. \& Östling, R. (2011), 'Identity and redistribution', Public Choice pp. 1-23.

List, J. A. (2007), 'On the interpretation of giving in dictator games', Journal of Political Economy 115(3), 482-493.

Loewen, P. J. (2011), 'Antipathy, affinity, and political participation: How our concern for others makes us vote', Canadian Journal of Political Science 43, 661-687.

Loewen, P. J., Cochrane, C. \& Arsenault, G. (2012), Empathy and political preferences. University of Toronto Working Paper.

Loewen, P. J., Lyle, G. \& Nachshen, J. S. (2007), An eight-item form of the empathy quotient (eq) and an application to charitable giving. Working paper.

Madestam, A., Shoag, D., Veuger, S. \& Yanagizawa-Drott, D. (2011), Do political protests matter? Evidence from the tea party movement. Working Paper, Havard University.

Manacorda, M., Miguel, E. \& Vigorito, A. (2011), 'Government transfers and political support', American Economic Journal: Applied Economics 3(3), 1-28. 
Mann, C. B. (2010), 'Is there backlash to social pressure? A large-scale field experiment on voter mobilization', Journal of Political Behavior 32(1), 387-407.

McGrath, J. (1984), Groups: Interaction and Process, Prentice-Hall, Englewood Cliffs.

Mondak, J. (2010), Personality and the foundations of political behavior, Cambridge Univ $\operatorname{Pr}$.

Mondak, J., Hibbing, M., Canache, D., Seligson, M. \& Anderson, M. (2010), 'Personality and civic engagement: An integrative framework for the study of trait effects on political behavior', American Political Science Review 104(1), 85-110.

Morton, R., Tyran, J.-R. \& Wengström, E. (2011), Income and ideology: How personality traits, cognitive abilities, and education shape political attitudes. Discussion Paper University of Copenhagen: No. 11-08.

Newcomb, T. (1961), The Acquaintance Process, Holt, Rinehart \& Winston, New York.

Page, B. I. \& Jones, C. C. (1979), 'Reciprocal effects of policy preferences, party loyalties and the vote', American Political Science Review 73(4), 4.

Richter, K. (2006), 'Wage arrears and economic voting in russia', American Political Science Review 100(1), 133-145.

Rodden, J. (2010), 'The geographic distribution of political preferences', Annual Review of Political Science 13(1), 321-340.

Settle, J., Dawes, C. \& Fowler, J. (2009), 'The heritability of partisan attachment', Political Research Quarterly 62(3), 601-613.

Shayo, M. (2009), 'A model of social identity with an application to political economy: Nation, class, and redistribution', American Political Science Review 103(2), 147-174. 
Sheingold, C. A. (1973), 'Social networks and voting: The resurrection of a research agenda', American Sociological Review 38(6), 712-720.

Tam Cho, W. K., Gimpel, J. G. \& Dyck, J. J. (2006), 'Residential concentration, political socialization and voter turnout', Journal of Politics 68(1), 156-167.

Tedin, K. L. (1980), 'Assessing peer and parent influence on adolescent political attitudes', American Journal of Political Science 24(1), 136-154.

Wakabayashi, A., Baron-Cohen, S., Wheelwright, S., Goldenfeld, N., Delaney, J., Fine, D., Smith, R. \& Weil, L. (2006), 'Development of short forms of the empathy quotient (eqshort) and the systemizing quotient (sq-short)', Personality and Individual Differences 41, 929-940.

Weatherford, M. S. (1982), 'Interpersonal networks and political behavior', American Journal of Political Science 26(1), 117-143.

Zaller, J. (1992), The Nature and Origins of Mass Opinion, Cambridge University Press.

\section{A Representativeness of Country Studies}

[TABLE A1 HERE]

\section{B Additional Information about Canadian Study}

The Canadian study was conducted in May 2007 by a Canadian commercial public opinion research firm. As the survey was conducted online, respondents were required to login to the survey using a unique identification. People completing the survey for the first time responded to a number of screening questions, including a query about their partisan identification. All respondents were presented with a series of questions about recent news exposure, 
attention to federal and provincial politics, and views on various politicians. Subjects then completed an eight-item measure of empathy based on a larger instrument (see Loewen et al. 2007, Wakabayashi et al. 2006) as well as four dictator games. Following this, subjects answered questions concerning their support for public spending, past charitable giving, views of the public service, and views of recent political events.

The dictator game experiment consisted of four iterations. Subjects read an introduction to the game and were then presented with instructions. Upon being informed that they would have four chances to win one of four $\$ 100$ prizes at the end of the survey, subjects were asked how much they would like to share with a completely anonymous individual about whom they know nothing and who would never know their identity. Subjects entered their preferred split. The game was then repeated three times with subjects being informed that the anonymous recipient supports the Conservative, Liberal, or New Democratic parties. The order of the recipients was randomized. Respondents could give away any amount between $\$ 0$ and $\$ 100$.

Table A2 shows the exact wording of the survey questions (excluding control variables) that are included in the analysis in this paper.

[TABLE A2 HERE]

\section{Additional Information about Swedish Study}

The survey was conducted in May 2011 by the commercial public opinion research firm SIFO using their Internet panel. The survey first asked subjects about their political preferences, party identification and the WTP questions. These questions were followed by a number of questions about background characteristics (gender, age, income, education etc.). After these questions, subjects were asked how they would like to split 1000 SEK with another anonymous participant in the study. Subjects were told that they would be faced with a

number of such decisions and that two proposers and two recipients would be randomly 
selected for payment for each decision. Subjects were asked five different questions, so in total 10 proposers and 10 receivers were paid. At end of the survey subjects were asked to state their postal address and 20 randomly selected subjects were subsequently contacted to administer payments.

The five dictator game decisions were shown on a separate screen with no possibility to go back and revise earlier decisions. The first decision was how to allocate 1000 SEK between themselves and any randomly selected participant in the study. For half of the subjects, the second question was how much they would donate to someone to the left and the third question how much they would give to someone to the right. The other half of the subjects took these decisions in reverse order. Finally, subjects were asked to state how much they would like to give to someone from the largest right-wing party ("Moderaterna") and to someone form the largest left-wing party ("Socialdemokraterna"), and the order of the two questions was again randomized.

Table A3 shows the exact wording of the survey questions that are included in the analysis in this paper.

[TABLE A3 HERE]

\section{Additional Information about UK Study}

The British study was conducted in December 2009 and January 2010 (Wave 1), and June 2010 (Wave 6) as a part of the British Cooperative Campaign Analysis Project. The study was conducted by an international public opinion research firm. The survey included dozens of questions on respondents' political views and attitudes, campaign attention and contact, social and traditional media usage, and demographics. These questions were posed in the first wave. The dictator games and willingness to pay questions were all asked in the final wave of the study. The dictator game experiment consisted of four iterations. Subjects read an introduction to the game. They were then informed that they would be eligible 
to win additional prizes worth 10,000 points (which equals 100 GBP). Subjects were told that the amount of the prize they would receive would depend on their decisions in the four games which followed. They were then asked how much they would like to share with an anonymous recipient, an anonymous recipient who typically supports the Conservative party, another who typically supports the Labour party, and another recipient who typically supports the Liberal Democrats. Recipient order was randomized. Respondents could allocate any amount of points between 0 and 10000 .

Table A4 shows the exact wording of all the survey questions that are included in the analysis in this paper.

[TABLE A4 HERE]

\section{E Additional information about US Study}

Subjects in the US study completed their experimental sessions in a computer lab. Each session lasted approximately 60 minutes. Subjects were asked a number of screening questions, including demographic information and their partisan identification. Subjects where asked a few political questions, including the WTP questions. This was followed by some unrelated questions about theory of mind. These were followed by some questions about political preferences. After completing these questions, subjects read instructions for the dictator game. Subjects were instructed that three prizes of $\$ 100$ would be drawn according to their decisions in the three tasks that followed. In a first-round, they were asked how much they would donate to a completely anonymous individual. Subjects were then asked how much they would donate to a conservative recipient or how much they would donate to a Republican recipient. Finally, they were asked how much they would donate to a liberal recipient or to a Democratic recipient. After completing the dictator games, subjects completed a number of other tasks before the termination of the study.

Table A5 shows the exact wording of the questions that are included in the analysis in 
this paper.

[TABLE A5 HERE]

\section{F Order Effects}

[TABLE A6 HERE]

\section{G Swedish Pilot Study}

\section{G.1 Study Design}

The Swedish pilot study was carried out as classroom experiments between April 2008 and May 2009 in four different upper secondary schools in the Stockholm area. ${ }^{21}$ The subjects were between the age of 16 to 19 and attended study programs within engineering, natural science or social science. The total number of participating students was 186.

Two different classes (seated in different classrooms) took part in each experimental session which lasted about 45 minutes. The framing of the experiment was made as neutral as possible. The experiment proceeded in three different steps.

In the first step the subjects were asked to state their political orientation as predominately "left" or "right" on a preprinted answer sheet. ${ }^{22}$ At this point they did not know the purpose of the question nor did they have any information about the upcoming stages of the experiment. The answers were collected while the subjects remained quiet and seated. Each subject was then randomly matched with another subject in the other classroom who

\footnotetext{
${ }^{21}$ The teachers of the particular classes were present during the experiment. Although the presence of the teacher could make the subjects perceive the experiment as less anonymous, it seemed necessary in order to ensure adequate control of the subjects, enhance authority, and motivate subjects to show up.

${ }^{22}$ For the purpose of identification, each subject was assigned a random combination of numbers printed on small pieces of paper, wherein only a specific number was used as the identification figure. This disguised system of identification ensured anonymity, as it became very difficult for the subjects to identify themselves as well as others. This was especially important since it was plausible to assume that the subjects knew each other and would communicate after the experiment. The procedure also enhanced the subjects' perception of anonymity towards us as experimenters and toward the teachers.
} 
in turn was paired with a third subject in the first classroom. This procedure thus formed a chain of subjects in which every subject acted both as donor and as recipient to different, randomly assigned subjects. We did not pair specific couples since we wanted to remove the possibility that subjects engaged in some kind of reciprocal behavior. Subjects did not know with which two persons they interacted and were told that it would not be revealed after the experiment.

In the second step, the subjects were given the instructions of the dictator game and an envelope with information regarding the political orientation of their randomly assigned recipient, i.e., whether the recipient considered him- or herself as primarily "left" or "right" on the political spectrum. Subjects received no other information regarding the identity of the recipient. We informed subjects of the recipient's political orientation since we wanted to test for an in-group effect, i.e., whether dictators are more generous toward recipients with the same political orientation. After the subjects were provided with the political orientation of the recipient, they were asked to split the endowment of 100 SEK (approximately $\$ 10$ to $\$ 15)$ between themselves and the recipient and indicate their choice on an answer sheet to be placed in a sealed envelope. ${ }^{23}$ The envelopes were collected after everyone had made their decision.

After the experiment, we randomly selected the subjects in one classroom the role of "dictators". The subjects in the remaining classroom were assigned the role of "recipients". That is, money was only distributed according to half of the subjects' decisions as dictators. The subjects were informed about the amount of money they had earned (and thus indirectly whether they had been assigned the role of donor or recipient) in a letter sent by regular mail about two weeks after the experiment. This letter also contained the money that the subject earned in the experiment.

In the third and last stage of the experiment, the subjects were given a short question-

\footnotetext{
${ }^{23}$ For practical purposes, the names and addresses of each participant were collected together with the dictator decisions. It is possible that this reduced the perception of anonymity towards us as experimenters, which is likely to lead to increased donations. However, for this to invalidate our results, it must be the case that the sensitivity to perceived anonymity in the dictator game is related to political orientation.
} 
naire with a battery of questions regarding their sex, religious and political views, family background, interest in politics and beliefs about the generosity and trustworthiness of people with different political views. Subjects were also asked to provide a written motivation for their particular choice of splitting the endowment. The subjects were explicitly informed that the experiment was over and that the questionnaire constituted the final step of the study and that their answers would not be revealed to anyone else.

\section{G.2 Independent Variables}

We include dummy variables for the donor's gender and whether donors responded that they are religious or not. In addition, we include the number of parents with university education $(0,1$ or 2$)$, how interested the participant is in politics on a four-point scale and how often the participant reads newspapers on a four point scale. We did not collect information about age since all subjects were of very similar age. Parents' education serves as a proxy for socioeconomic status of the student (there is likely to be little variation in student income and we did not expect students to be well-informed about the income of their parents).

The differences between left- and right-wing subjects are small in terms of these background variables. The only statistically significant differences are that women tend to be more leftist $(p=0.093)$ and those whose parents have low levels of education are more likely to identify themselves as leftist $(p=0.072)$.

\section{G.3 Results}

Since we did not include the possibility to donate to a completely anonymous recipient, we cannot estimate specification (1) and (2). Table A7 therefore only displays the result for specifications (3) and (4). We estimate the same specification as for the other studies, but we only have one observation for each individual (in contrast to the survey studies), so we do not cluster the standard errors in these regressions. 


\section{[TABLE A7 HERE]}

The first column displays the results without any controls. In this case, the right-wing partisanship is associated with an increase in donations of 19.80 percentage points and the coefficient is strongly statistically different from zero. Dictators who are faced with a recipient with similar political views give 2.87 percentage units more on average, but the effect is small and not statistically different from zero. As shown in the second and third columns, including the set of control variables implies a weaker relationship between right-wing partisanship and generosity. The main reason is the inclusion of school fixed effects - in one of the schools there was a larger proportion of right-wing subjects and average donations were lower in that school.

The last three columns of Table A7 includes the interaction between donor and recipient partisanship in order to test whether the effect of the recipient's partisanship varies between right- and left-wing donors. The interaction effect is not statistically significant.

As a robustness test, we re-run our regressions removing the 12 subjects who gave "inconsistent" responses on their political orientation in the first stage and in the subsequent questionnaire. The results do not change appreciably from this test (the size of the coefficients of interest becomes slightly larger, but the levels of statistical significance are the same).

One potential reason why left-wing donors are more generous is that political orientation is correlated with a belief that others will be more generous in the dictator game. However, the mean responses on questions about the generosity of other people in the questionnaire are almost exactly the same for people with left-wing and right-wing orientation, and controlling for the perceived level of generosity among others does not affect the estimates reported in Table A7. People with right-wing opinions are somewhat less likely to have friends of both right-wing and left-wing orientation, but controlling for this in regression does not change the results appreciably either. We interpret this as tentative evidence that right-wing donors were not, in general, motivated by a belief that they would, themselves, receive small or no 
donations if the roles of donor and recipient were reversed. The written comments support this notion. The majority of dictators who choose to send nothing or only a small amount of money motivated this choice by pure self-interest (e.g., "I wanted as much money as possible for myself"). In sharp contrast, many dictators who choose to send 50 percent motivate this choice with concerns for fairness (e.g., "I don't think it is fair if I keep all the money to myself"). 


\begin{tabular}{|c|c|c|c|c|c|c|c|c|c|c|c|c|}
\hline Political preferences & \multicolumn{3}{|c|}{ Canada } & \multicolumn{3}{|c|}{ Sweden } & \multicolumn{3}{|c|}{ United Kingdom } & \multicolumn{3}{|c|}{ United States } \\
\hline Right-wing (1-10) & & & & $\begin{array}{l}-0.933^{* * *} \\
(0.233)\end{array}$ & $\begin{array}{l}-0.812^{* * *} \\
(0.248)\end{array}$ & $\begin{array}{l}-1.027^{* * *} \\
(0.267)\end{array}$ & $\begin{array}{l}-0.499^{*} \\
(0.283)\end{array}$ & $\begin{array}{l}-0.566^{*} \\
(0.319)\end{array}$ & $\begin{array}{l}-0.298 \\
(0.346)\end{array}$ & $\begin{array}{l}-1.547^{* *} \\
(0.679)\end{array}$ & $\begin{array}{l}-1.532^{* *} \\
(0.697)\end{array}$ & $\begin{array}{l}-1.654^{* *} \\
(0.762)\end{array}$ \\
\hline$N$ & & & & 951 & 829 & 829 & 1247 & 1009 & 1009 & 253 & 246 & 246 \\
\hline Increase taxes (1-10) & & & & & & & $\begin{array}{l}0.631^{*} \\
(0.332)\end{array}$ & $\begin{array}{l}0.674^{*} \\
(0.366)\end{array}$ & $\begin{array}{l}0.627 \\
(0.385)\end{array}$ & $\begin{array}{l}1.153^{*} \\
(0.669)\end{array}$ & $\begin{array}{l}1.105 \\
(0.676)\end{array}$ & $\begin{array}{l}1.104 \\
(0.739)\end{array}$ \\
\hline$N$ & & & & & & & 1352 & 1095 & 1095 & 255 & 248 & 248 \\
\hline Increase income ineq. (1-10) & & & & & & & & & & $\begin{array}{l}-1.123^{* *} \\
(0.548)\end{array}$ & $\begin{array}{l}-1.084^{*} \\
(0.558)\end{array}$ & $\begin{array}{l}-1.290 * * \\
(0.650)\end{array}$ \\
\hline$N$ & & & & & & & & & & 254 & 247 & 247 \\
\hline Government less resp. (1-10) & & & & $\begin{array}{l}-0.509 * \\
(0.259)\end{array}$ & $\begin{array}{l}-0.276 \\
(0.284)\end{array}$ & $\begin{array}{l}-0.335 \\
(0.302)\end{array}$ & & & & $\begin{array}{l}-0.632 \\
(0.549)\end{array}$ & $\begin{array}{l}-0.751 \\
(0.544)\end{array}$ & $\begin{array}{l}-0.981 \\
(0.638)\end{array}$ \\
\hline$N$ & & & & 961 & 833 & 833 & & & & 250 & 243 & 243 \\
\hline WTP public goods & & & & & & & & & & & & \\
\hline Climate & $\begin{array}{l}1.146^{*} \\
(0.634)\end{array}$ & $\begin{array}{l}0.996 \\
(0.675)\end{array}$ & $\begin{array}{l}1.510^{* *} \\
(0.715)\end{array}$ & $\begin{array}{l}2.947^{* *} \\
(1.339)\end{array}$ & $\begin{array}{l}2.789^{*} \\
(1.432)\end{array}$ & $\begin{array}{l}3.661^{* *} \\
(1.579)\end{array}$ & & & & $\begin{array}{l}2.540 \\
(2.099)\end{array}$ & $\begin{array}{l}2.832 \\
(2.127)\end{array}$ & $\begin{array}{l}3.733^{*} \\
(2.247)\end{array}$ \\
\hline$N$ & 2054 & 1790 & 1790 & 976 & 844 & 844 & & & & 259 & 252 & 252 \\
\hline Medical care & $\begin{array}{l}3.697^{* * *} \\
(0.771)\end{array}$ & $\begin{array}{l}3.776^{* * *} \\
(0.825)\end{array}$ & $\begin{array}{l}4.125 * * * \\
(0.826)\end{array}$ & $\begin{array}{l}1.335 \\
(2.035)\end{array}$ & $\begin{array}{l}0.389 \\
(2.405)\end{array}$ & $\begin{array}{l}1.705 \\
(2.662)\end{array}$ & $\begin{array}{l}1.457^{* * *} \\
(0.564)\end{array}$ & $\begin{array}{l}1.596 * * \\
(0.636)\end{array}$ & $\begin{array}{l}1.675^{* *} \\
(0.658)\end{array}$ & $\begin{array}{l}5.376^{* *} \\
(2.223)\end{array}$ & $\begin{array}{l}5.617^{* *} \\
(2.248)\end{array}$ & $\begin{array}{l}6.439^{* * *} \\
(2.427)\end{array}$ \\
\hline$N$ & 1981 & 1729 & 1729 & 976 & 844 & 844 & 1365 & 1104 & 1104 & 257 & 250 & 250 \\
\hline Tuition & $\begin{array}{l}4.123^{* * *} \\
(0.873)\end{array}$ & $\begin{array}{l}3.981 * * * \\
(0.885)\end{array}$ & $\begin{array}{l}4.308^{* * *} \\
(0.921)\end{array}$ & $\begin{array}{l}5.335^{* * *} \\
(1.134)\end{array}$ & $\begin{array}{l}4.934^{* * *} \\
(1.308)\end{array}$ & $\begin{array}{l}5.105^{* * *} \\
(1.381)\end{array}$ & $\begin{array}{l}1.770^{* * *} \\
(0.460)\end{array}$ & $\begin{array}{l}2.218^{* * *} \\
(0.521)\end{array}$ & $\begin{array}{l}2.126^{* * *} \\
(0.538)\end{array}$ & $\begin{array}{l}2.908 \\
(1.900)\end{array}$ & $\begin{array}{l}3.521^{*} \\
(1.929)\end{array}$ & $\begin{array}{l}4.383^{* *} \\
(1.968)\end{array}$ \\
\hline N & 2648 & 2288 & 2288 & 976 & 844 & 844 & 1352 & 1093 & 1093 & 257 & 251 & 251 \\
\hline CONTROL VARIABLES & No & No & Yes & No & No & Yes & No & No & Yes & No & No & Yes \\
\hline SAMPLE RESTRICTION & No & $\begin{array}{l}\text { Controls } \\
\text { observed }\end{array}$ & $\begin{array}{l}\text { Controls } \\
\text { observed }\end{array}$ & No & $\begin{array}{l}\text { Controls } \\
\text { observed }\end{array}$ & $\begin{array}{l}\text { Controls } \\
\text { observed }\end{array}$ & No & $\begin{array}{l}\text { Controls } \\
\text { observed }\end{array}$ & $\begin{array}{l}\text { Controls } \\
\text { observed }\end{array}$ & No & $\begin{array}{l}\text { Controls } \\
\text { observed }\end{array}$ & $\begin{array}{l}\text { Controls } \\
\text { observed }\end{array}$ \\
\hline
\end{tabular}

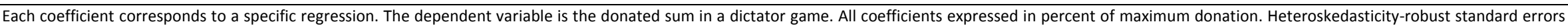

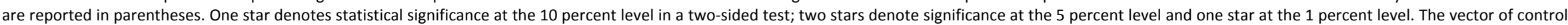

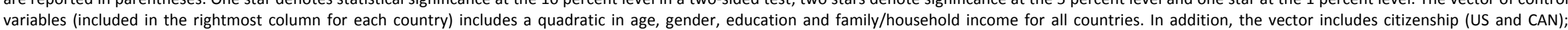

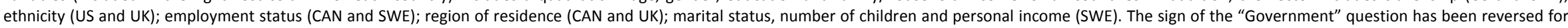

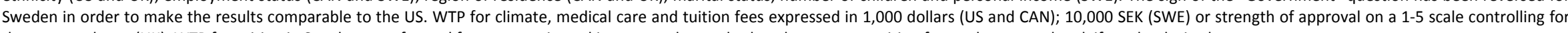
the proposed sum (UK). WTP for tuition in Sweden transformed from a question asking respondents whether they want to tuition fees to be enacted and, if so, the desired amount. 
Table 2. Partisanship and Altruism

\begin{tabular}{|c|c|c|c|c|c|c|c|c|c|c|c|}
\hline \multicolumn{3}{|c|}{ Canada } & \multicolumn{3}{|c|}{ Sweden } & \multicolumn{3}{|c|}{ United Kingdom } & \multicolumn{3}{|c|}{ United States } \\
\hline \multicolumn{3}{|c|}{ Excluded party: New Democrat } & \multicolumn{3}{|c|}{ Excluded political bloc: Left-wing } & \multicolumn{3}{|c|}{ Excluded party: Labour } & \multicolumn{3}{|c|}{ Excluded party: Democratic party } \\
\hline \multicolumn{12}{|c|}{ Recipient partisanship unknown } \\
\hline \multirow[t]{2}{*}{ Conservative } & $-2.941 * *$ & $-4.429 * * *$ & Right-wing bloc & $-4.574 * * *$ & $-4.540^{* *}$ & Conservative & 1.352 & 2.257 & Republican & -2.491 & -1.968 \\
\hline & $(1.404)$ & $(1.594)$ & & $(1.510)$ & $(1.793)$ & & $(1.724)$ & $(2.987)$ & & $(4.658)$ & $(8.477)$ \\
\hline \multirow[t]{2}{*}{ Liberal } & $-2.473^{*}$ & $-2.843^{*}$ & N & 729 & 516 & Liberal democrats & 1.526 & $9.159 *$ & & & \\
\hline & $(1.351)$ & (1.547) & & & & & (2.545) & (5.514) & & & \\
\hline$N$ & 2562 & 1979 & & & & N & 757 & 279 & N & 187 & 72 \\
\hline \multicolumn{12}{|c|}{ Recipient partisanship known } \\
\hline \multirow[t]{2}{*}{ Conservative } & $-5.023 * * *$ & $-5.602 * * *$ & Right-wing bloc & -1.011 & -1.000 & Conservative & $2.841^{*}$ & 2.502 & Republican & 3.568 & -1.563 \\
\hline & $(1.111)$ & $(1.277)$ & & $(1.521)$ & $(1.816)$ & & $(1.458)$ & $(2.397)$ & & $(4.827)$ & (7.410) \\
\hline \multirow[t]{2}{*}{ Liberal } & $-3.199 * * *$ & -2.845 & Same & $10.459 * * *$ & $12.030 * * *$ & Liberal democrats & 2.797 & $10.821^{* *}$ & Same & $4.655^{*}$ & 4.867 \\
\hline & $(1.133)$ & $(1.269)$ & & $(0.7847)$ & $(0.958)$ & & $(2.044)$ & $(4.239)$ & & (2.371) & (3.088) \\
\hline \multirow[t]{2}{*}{ Same } & $9.280 * * *$ & $10.946^{* * *}$ & $N /$ Individuals & $1452 / 726$ & $1026 / 513$ & Same & $5.530 * * *$ & $8.339 * * *$ & & & \\
\hline & $(0.383)$ & $(0.456)$ & & & & & $(0.518)$ & $(1.049)$ & & & \\
\hline$N /$ Individuals & $7644 / 2548$ & $5898 / 1966$ & & & & $N /$ Individuals & $2271 / 757$ & $837 / 279$ & $N$ / Individuals & $187 / 140$ & $62 / 51$ \\
\hline \multirow[t]{2}{*}{ Conservative } & $-3.674 * * *$ & $-4.499 * * *$ & Right-wing bloc & $3.520^{*}$ & 3.157 & Conservative & $4.063^{* * *}$ & $4.441^{*}$ & Republican & 8.330 & -5.450 \\
\hline & $(1.159)$ & $(1.312)$ & & $(1.846)$ & $(2.223)$ & & $(1.453)$ & $(2.424)$ & & $(6.564)$ & (8.229) \\
\hline \multirow[t]{2}{*}{ Liberal } & -0.700 & -0.569 & Same & $15.389 * * *$ & $16.439^{* * *}$ & Liberal democrats & 3.184 & $9.063^{*}$ & Same & $6.439 * *$ & 2.988 \\
\hline & (1.129) & (1.296) & & $(1.235)$ & $(1.482)$ & & (2.019) & $(4.740)$ & & (2.469) & (3.654) \\
\hline \multirow[t]{2}{*}{ Same } & $14.023^{* * *}$ & $15.012^{* * *}$ & Right-wing bloc* Same & $-9.060 * * *$ & $-8.314^{* * *}$ & Same & $7.385^{* * *}$ & $10.738^{* * *}$ & Republican* Same & -9.169 & 8.059 \\
\hline & $(0.927)$ & $(1.030)$ & & $(1.561)$ & $(1.482)$ & & $(0.930)$ & $(1.755)$ & & (6.482) & (8.288) \\
\hline \multirow[t]{2}{*}{ Conservative * Same } & $-4.047^{* * *}$ & $-3.309 * * *$ & $N /$ Individuals & $1452 / 726$ & $1026 / 513$ & Conservative* Same & $-3.667^{* * *}$ & $-5.817^{* * *}$ & & & \\
\hline & $(1.145)$ & $(1.295)$ & & & & & (1.121) & (2.103) & & & \\
\hline \multirow[t]{2}{*}{ Liberal* Same } & $-7.497 * * *$ & $-6.828 * * *$ & & & & Liberal dem.* Same & -1.161 & 5.273 & & & \\
\hline & $(1.056)$ & $(1.211)$ & & & & & $(1.759)$ & $(5.222)$ & & & \\
\hline \multirow[t]{2}{*}{$N /$ Individuals } & $7644 / 2548$ & $5898 / 1966$ & & & & $N /$ Individuals & $2271 / 757$ & $879 / 279$ & $N$ / Individuals & $187 / 140$ & $62 / 51$ \\
\hline & All partisans & $\begin{array}{l}\text { Strong } \\
\text { partisans }\end{array}$ & & All partisans & $\begin{array}{l}\text { Strong } \\
\text { partisans }\end{array}$ & & $\begin{array}{l}\text { All } \\
\text { partisans }\end{array}$ & $\begin{array}{l}\text { Strong } \\
\text { partisans }\end{array}$ & & All partisans & $\begin{array}{l}\text { Strong } \\
\text { partisans }\end{array}$ \\
\hline
\end{tabular}

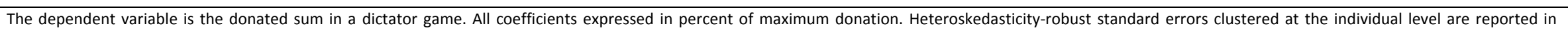

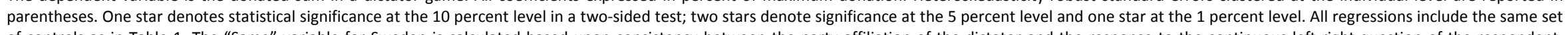

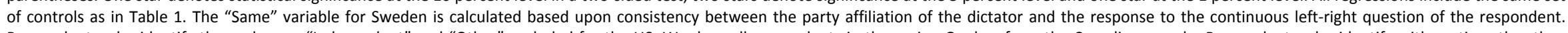

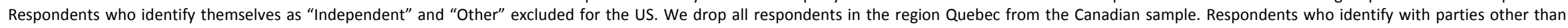

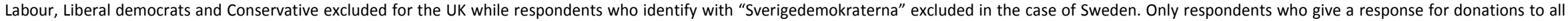
types of recipients included in the sample. 
Table 3. Partisanship and Political Preferences

\begin{tabular}{|c|c|c|c|c|c|c|c|c|c|c|c|}
\hline \multicolumn{3}{|c|}{ Canada } & \multicolumn{3}{|c|}{ Sweden } & \multicolumn{3}{|c|}{ United Kingdom } & \multicolumn{3}{|c|}{ United States } \\
\hline \multirow{2}{*}{\multicolumn{3}{|c|}{$\begin{array}{l}\text { Excluded party: New Democrat } \\
\text { Right-wing }\end{array}$}} & \multicolumn{3}{|c|}{ Excluded political bloc: Left-wing } & \multicolumn{3}{|c|}{ Excluded party: Labour } & & & \\
\hline & & & & & & & & & & & \\
\hline & & & Right-wing block & $\begin{array}{l}4.724^{* * *} \\
(0.107)\end{array}$ & $\begin{array}{l}5.339^{* * *} \\
(0.125)\end{array}$ & Conservative & $\begin{array}{l}2.768^{* * *} \\
(0.137)\end{array}$ & $\begin{array}{l}3.944^{* * *} \\
(0.244)\end{array}$ & Republican & $\begin{array}{l}3.134^{* * *} \\
(0.279)\end{array}$ & $\begin{array}{l}4.959 * * * \\
(0.611)\end{array}$ \\
\hline & & & N & 762 & 538 & Liberal democrats & $0.774^{* * *}$ & $1.116^{* * *}$ & N & 183 & 71 \\
\hline & & & & & & & $(0.193)$ & $(0.398)$ & & & \\
\hline & & & & & & N & 691 & 263 & & & \\
\hline \multicolumn{12}{|l|}{ Increase taxes } \\
\hline & & & & & & Conservative & $-1.530^{* * *}$ & $-2.002^{* * *}$ & Republican & $-2.724^{* * *}$ & $-4.214^{* * *}$ \\
\hline & & & & & & & $(0.142)$ & $(0.253)$ & & $(0.351)$ & $(0.721)$ \\
\hline & & & & & & Liberal democrats & $-0.360^{*}$ & -0.056 & $N$ & 183 & 70 \\
\hline & & & & & & & $(0.193)$ & $(0.444)$ & & & \\
\hline & & & & & & $N$ & 725 & 267 & & & \\
\hline \multicolumn{12}{|c|}{ Government less responsibility } \\
\hline & & & Right-wing block & $2.732^{* * *}$ & $3.069 * * *$ & & & & Republican & $2.766^{* * *}$ & $4.624^{* * *}$ \\
\hline & & & & $(0.159)$ & $(0.201)$ & & & & & $(0.446)$ & $(1.013)$ \\
\hline & & & N & 763 & 537 & & & & N & 179 & 67 \\
\hline \multicolumn{12}{|c|}{ WTP Medical Care } \\
\hline \multirow[t]{3}{*}{ Conservative } & $-0.387^{* * *}$ & - & Right-wing block & $-0.106 * * *$ & $-0.117^{* * *}$ & Conservative & $-0.242^{* *}$ & -0.260 & Republican & $-0.226^{* *}$ & $-0.634^{* *}$ \\
\hline & & $0.450^{* * *}$ & & & & & & & & & \\
\hline & $(0.073)$ & $(0.082)$ & & $(0.028)$ & $(0.034)$ & & $(0.096)$ & $(0.159)$ & & $(0.103)$ & $(0.242)$ \\
\hline \multirow[t]{3}{*}{ Liberal } & $-0.207^{* * *}$ & - & N & 768 & 539 & Liberal democrats & -0.006 & -0.395 & $N$ & 185 & 72 \\
\hline & & $0.227^{* * *}$ & & & & & & & & & \\
\hline & $(0.072)$ & $(0.082)$ & & & & & $(0.137)$ & $(0.322)$ & & & \\
\hline$N$ & 983 & 756 & & & & $N$ & 757 & 279 & & & \\
\hline \multicolumn{12}{|l|}{ WTP Tuition } \\
\hline \multirow[t]{3}{*}{ Conservative } & $-0.244 * * *$ & - & Right-wing block & $-0.175 * * *$ & $-0.180 * * *$ & Conservative & $-0.528 * * *$ & $-0.776 * * *$ & Republican & $-0.459 * * *$ & $-0.648 * *$ \\
\hline & & $0.308^{* * *}$ & & & & & & & & & \\
\hline & $(0.050)$ & $(0.057)$ & & $(0.038)$ & $(0.047)$ & & $(0.113)$ & $(0.185)$ & & $(0.134)$ & $(0.267)$ \\
\hline \multirow[t]{2}{*}{ Liberal } & $-0.089 *$ & $-0.139 * *$ & N & 768 & 539 & Liberal democrats & -0.112 & -0.267 & $N$ & 186 & 72 \\
\hline & $(0.050)$ & $(0.058)$ & & & & & $(0.163)$ & $(0.185)$ & & & \\
\hline \multirow[t]{2}{*}{$N$} & 1308 & 997 & & & & N & 734 & 269 & & & \\
\hline & $\begin{array}{l}\text { All } \\
\text { partisans }\end{array}$ & $\begin{array}{l}\text { Strong } \\
\text { partisans }\end{array}$ & & All partisans & $\begin{array}{l}\text { Strong } \\
\text { partisans }\end{array}$ & & All partisans & $\begin{array}{l}\text { Strong } \\
\text { partisans }\end{array}$ & & All partisans & $\begin{array}{l}\text { Strong } \\
\text { partisans }\end{array}$ \\
\hline
\end{tabular}

The dependent variables are political opinions measured on a 1-10 scale where 10 implies that respondents approve of the statement implied by the question, or WTP for public goods. WTP for climate, medical care and tuition fees expressed in 1,000 dollars (US and CAN); 10,000 SEK (SWE) or strength of approval on a 1-5 scale controlling for the proposed sum (UK). WTP for tuition in Sweden transformed from a question asking respondents whether they want to tuition fees to be enacted and, if so, the desired amount. WTP for drugs for cancer treatment expressed in terms of hours waiting time for non-emergency care, except for the UK where WTP is measured as strength of approval on a 1-5 scale controlling for proposed waiting time. All regressions include the same set of controls as in Table 1. The same sample restrictions as in Table 2 are imposed for each country. Heteroskedasticity-robust standard errors are reported in parentheses. One star denotes statistical significance at the 10 percent level in a two-sided test; two stars denote significance at the 5 percent level and one star at the 1 percent level. 
Table 4. Political Preferences and Altruism - by Degree of Partisanship

\begin{tabular}{|c|c|c|c|c|c|c|c|c|}
\hline & \multicolumn{3}{|c|}{ United States } & \multirow{2}{*}{ Canada } & \multicolumn{2}{|c|}{ United Kingdom } & \multirow{2}{*}{\multicolumn{2}{|c|}{$\begin{array}{l}\text { Sweden } \\
\text { Non-partisan }\end{array}$}} \\
\hline & Partisan & Non-partisan & Partisan & & Partisan & Non-partisan & & \\
\hline \multicolumn{9}{|l|}{ Political preferences } \\
\hline \multirow[t]{2}{*}{ Right-wing (1-10) } & -0.799 & 1.565 & & & -0.421 & 0.281 & $-1.012^{* * *}$ & 0.756 \\
\hline & $(0.886)$ & (3.473) & & & $(0.397)$ & $(0.832)$ & $(0.297)$ & $(0.632)$ \\
\hline$N$ & 182 & 50 & & & 716 & 293 & 529 & 300 \\
\hline \multirow[t]{2}{*}{ Increase taxes (1-10) } & 0.111 & 1.074 & & & 0.507 & 1.049 & & \\
\hline & $(0.922)$ & (1.684) & & & $(0.437)$ & $(0.806)$ & & \\
\hline$N$ & 182 & 51 & & & 756 & 339 & & \\
\hline \multirow[t]{2}{*}{ Increase income ineq. (1-10) } & -0.375 & $-2.487 *$ & & & & & & \\
\hline & $(0.759)$ & $(1.403)$ & & & & & & \\
\hline$N$ & 182 & 52 & & & & & & \\
\hline Government less resp. (1-10) & $\begin{array}{l}-0.024 \\
(0.777)\end{array}$ & $\begin{array}{l}-1.305 \\
(1.679)\end{array}$ & & & & & $\begin{array}{l}-0.457 \\
(0.348)\end{array}$ & $\begin{array}{l}0.263 \\
(0.593)\end{array}$ \\
\hline$N$ & 179 & 50 & & & & & 530 & 303 \\
\hline \multicolumn{9}{|l|}{ WTP public goods } \\
\hline \multirow[t]{2}{*}{ Climate } & 1.812 & -1.677 & 1.196 & $2.201^{*}$ & & & $3.743^{*}$ & $3.976^{*}$ \\
\hline & $(2.547)$ & (5.965) & $(0.911)$ & $(1.213)$ & & & $(2.002)$ & $(2.316)$ \\
\hline$N$ & 185 & 52 & 1164 & 626 & & & 532 & 312 \\
\hline \multirow[t]{2}{*}{ Medical care } & $5.003^{*}$ & -0.293 & $3.676 * * *$ & $5.045^{* * *}$ & 0.920 & $3.248^{* *}$ & 2.264 & 1.535 \\
\hline & $(2.894)$ & $(7.603)$ & $(1.038)$ & $(1.414)$ & $(0.746)$ & $(1.375)$ & (2.251) & $(4.943)$ \\
\hline$N$ & 184 & 51 & 1138 & 591 & 757 & 347 & 532 & 312 \\
\hline \multirow[t]{2}{*}{ Tuition } & 3.379 & -2.202 & $4.670 * * *$ & $3.597^{* *}$ & $1.152^{*}$ & $4.297^{* * *}$ & $5.883 * * *$ & 3.808 \\
\hline & $(2.215)$ & $(6.280)$ & $(1.162)$ & (1.503) & $(0.640)$ & $(1.028)$ & (1.719) & (2.397) \\
\hline$N$ & 185 & 51 & 1502 & 786 & 748 & 345 & 532 & 312 \\
\hline
\end{tabular}


Table A1. Sample characteristics compared to population

\begin{tabular}{|c|c|c|c|c|c|c|c|c|}
\hline & \multicolumn{2}{|c|}{ Canada } & \multicolumn{2}{|c|}{ Sweden } & \multicolumn{2}{|c|}{ United Kingdom } & \multicolumn{2}{|c|}{ United States } \\
\hline & Sample & Population & Sample & Population & Sample & Population & Sample & Population \\
\hline Share female (\%) & 49.0 & 48.5 & 50.1 & 48.5 & 48.6 & 48.8 & 57.1 & 48.8 \\
\hline Average/median age & 50.1 & 42.1 & 52.6 & 43.1 & 49.0 & 41.1 & 20.9 & 38.2 \\
\hline Share married (\%) & & & 52.2 & 39.0 & & & & \\
\hline Share with completed tertiary education (\%) & 64.0 & 22.6 & 55.0 & 29.7 & 40.6 & 33.3 & $(100.0)$ & 27.9 \\
\hline Median monthly income (in local currency) & & & 23500 & 19333 & & 1633 & & \\
\hline Median annual household income (in local currency) & 70000 & 62390 & 450500 & N/A & 27500 & & 62000 & 51914 \\
\hline$N$ & \multicolumn{2}{|c|}{2,853} & \multicolumn{2}{|c|}{1,036} & \multicolumn{2}{|c|}{1,462} & \multicolumn{2}{|c|}{280} \\
\hline
\end{tabular}

Note: Income stated in intervals in the surveys. We calculate median income as the midpoint in the median interval. Refusal to report income is treated as a missing observation. Canadian sample restricted to those for whom we observe willingness to pay for public goods. Population averages for share female and average/median age from CIA World Factbook 2011. Share married, including widowed people (SWE) from Statistics Sweden Yearbook 2012. Tertiary education attainment from Statistics Canada (CAN, 15 years and above, 2006), Eurostat (SWE and UK, 15-65 years, 2011) and US Census (US, people aged 25 and above with bachelor's degree or higher, average 2006-2010). Median pre-tax incomes from Statistics Canada (CAN, median employment income of families 2010, single households excluded), Statistics Sweden Yearbook 2012 (SWE, 2009), HM Revenue \& Customs Personal Income Statistics 2009-2010 (UK, 2009-2010) and US Census (US, median household income 2006-2010). 
Table A2. Canada

\begin{tabular}{|c|c|c|}
\hline & Question & Response alternatives \\
\hline WTP Climate & $\begin{array}{l}\text { One proposed action to combat climate change and reduce air pollution is to raise } \\
\text { taxes on fossil fuels. Advocates of this claim that it would lead to cleaner air as well } \\
\text { as to improve people's health. Would you advocate a tax increase on fossil fuels if } \\
\text { the higher tax implied a total cost of X per year to heat your home, drive a car, } \\
\text { travel etc.? }\end{array}$ & $\$ 100, \$ 250, \$ 500, \$ 1000$ and $\$ 2000$. \\
\hline WTP Medical care & $\begin{array}{l}\text { Wait times for many medical procedures (such as cataract surgery and hip and knee } \\
\text { replacements) are currently longer than recommended by doctors. If tax dollars } \\
\text { were guaranteed to go to these priority areas and to reduce wait times, would you } \\
\text { support this policy if it were to cost X? }\end{array}$ & $\$ 2000, \$ 1500, \$ 1000, \$ 500$ and $\$ 100$ \\
\hline WTP Tuition & $\begin{array}{l}\text { Some politicians and policy groups propose making the first four years of university } \\
\text { free for all qualified students. This will result in greater accessibility to university } \\
\text { education. Would you support the elimination of tuition fees if it cost you X more } \\
\text { per year in taxes? }\end{array}$ & $\$ 100, \$ 250, \$ 500, \$ 1000$ and $\$ 2000$ \\
\hline Party ID & $\begin{array}{l}\text { Thinking about federal politics in Canada, generally speaking, do you usually think } \\
\text { of yourself as Liberal, Conservative, N.D.P. or none of these? }\end{array}$ & Conservative; Liberal; New Democrat; Other; None of these. \\
\hline Strength of partisanship & $\begin{array}{l}\text { And, generally speaking, how strongly do you think of } \\
\text { yourself as a (party)? }\end{array}$ & Very strongly; fairly strong; not strongly. \\
\hline Dictator game question (anonymous) & $\begin{array}{l}\text { At the end of this study, we'll be conducting a random draw for } \$ 100 \text {. All } \\
\text { respondents who complete the study will be eligible. If you win, you'll have the } \\
\text { chance to share your prize with another completely anonymous individual who also } \\
\text { completed the survey. Please keep in mind that whether you share your prize will } \\
\text { have no effect on your chances of winning! Also, you will never know the identity of } \\
\text { the person with whom you share the prize and they'll never know your identity. } \\
\text { Finally, remember that you don't have to share anything if you don't wish. If you } \\
\text { won the prize, how much would you give to a completely anonymous individual? }\end{array}$ & 0 to $\$ 100$. \\
\hline
\end{tabular}


Table A3. Sweden

\begin{tabular}{|c|c|c|}
\hline & Question & Response alternatives \\
\hline Right-wing & $\begin{array}{l}\text { Politics is usually divided into right- and left wing parties where Moderaterna, Kristdemokraterna, Folkpartiet } \\
\text { and Centerpartiet are considered right wing, and Socialdemokraterna, Miljöpartiet and Vänsterpartiet are } \\
\text { considered left wing. The numbers } 1-5 \text { on the scale below represents how left-wing you are; the numbers 6-10 } \\
\text { represent the right-wing. Number } 1 \text { implies that you are fully to the left; number } 10 \text { implies that you are } \\
\text { completely to the right. If you consider yourself to be something in between, choose the number that best } \\
\text { corresponds to your own political conviction. }\end{array}$ & 1. Left ... 10. Right. \\
\hline $\begin{array}{l}\text { Government less } \\
\text { responsibility }\end{array}$ & $\begin{array}{l}\text { How would you describe your opinion on the following scale from } 1 \text { to } 10.1 \text { being that you fully agree with the } \\
\text { statement to the left; } 10 \text { being that you fully agree with the statement to the right. If you regard your opinion } \\
\text { to be somewhere inbetween, choose the number that is best in accord with your own opinion. }\end{array}$ & $\begin{array}{l}\text { 1. People should take more responsibility for themselves. ... 10. The } \\
\text { Government should take more responsibility for providing all citizens } \\
\text { with what they need. }\end{array}$ \\
\hline WTP Climate & $\begin{array}{l}\text { One proposed action to combat climate change and reduce air pollution is to raise taxes on fossil fuels. } \\
\text { Advocates of this claim that it would lead to cleaner air as well as to improve people's health. Would you } \\
\text { advocate a tax increase on fossil fuels if the higher tax implied a total cost of X kronor per year to heat your } \\
\text { home, drive a car, travel etc.? }\end{array}$ & $\begin{array}{l}\text { Asked sequentially (yes/no question until negative answer): 500, } \\
1000,2500,5000,10000,20000 \text { and } 40000 \text { SEK. }\end{array}$ \\
\hline WTP Medical care & $\begin{array}{l}\text { The waiting times for a range of medical procedures within the health care system are by many considered to } \\
\text { be too long (surgery for hip-joints and cataracts are often mentioned as examples in the debate). How much } \\
\text { more would you be prepared to pay in tax per year to ensure the significant reduction of queues in the health } \\
\text { care system? }\end{array}$ & $\begin{array}{l}\text { Asked sequentially (yes/no question until negative answer): 500, } \\
1000,2500,5000,10000,20000 \text { and } 40000 \text { SEK. }\end{array}$ \\
\hline WTP Tuition & $\begin{array}{l}\text { Swedish universities have recently introduced tuition fees for foreign students. Some argue that a tuition fee } \\
\text { should also apply for Swedish students. How high do you think the tuition fees for Swedes should be if the } \\
\text { revenue was used to lower taxes for everyone? }\end{array}$ & $\begin{array}{l}\text { Six response alternatives: } 40000 \text { kronor per term, } 20000 \text { kronor per } \\
\text { term, } 20000 \text { kronor per term, } 5000 \text { kronor per term, } 1000 \text { kronor } \\
\text { per term, No tuition fees should be introduced. }\end{array}$ \\
\hline Party ID & When thinking about Swedish politics, do you usually view yourself as... & All parties in parliament and "none" \\
\hline $\begin{array}{l}\text { Strength of } \\
\text { partisanship }\end{array}$ & How strongly do you identify yourself with the party in the previous question? & $\begin{array}{l}\text { 1. Very strongly 2. Quite strongly. 3. Not particularly strongly. } 4 . \\
\text { Weakly. }\end{array}$ \\
\hline $\begin{array}{l}\text { Dictator game } \\
\text { question (anonymous) }\end{array}$ & $\begin{array}{l}\text { You will now face a couple of decisions where you have the opportunity to choose how you would distribute } \\
1000 \text { kronor between yourself and an anonymous counterpart who is also a participant in this study. For each } \\
\text { decision below, two participants will be chosen at random and they will both receive the amount they asked for } \\
\text { out of the } 1000 \text { kronor and the remainder will be paid out to a randomly selected counterpart. Participants in } \\
\text { the study constitute a representative sample of the population and your decision remains anonymous to other } \\
\text { participants in the study. }\end{array}$ & $\begin{array}{l}\text { If the recipient is another randomly selected participant in this study I } \\
\text { want to keep___ kronor and give ___ kronor to the counterpart. }\end{array}$ \\
\hline
\end{tabular}
participants in the study. 
Table A4. United Kingdom

\begin{tabular}{|c|c|c|}
\hline & Question & Response alternatives \\
\hline Right-wing & $\begin{array}{l}\text { In politics, people sometimes talk about parties and politicians as being on the left or right. } \\
\text { Using the } 0 \text { to } 10 \text { scale on this screen, where the end marked } 0 \text { means left and the end } \\
\text { marked } 10 \text { means right, where would you place yourself on this scale? }\end{array}$ & 0 . Left ... 10. Right. \\
\hline Increase taxes & Which statement comes closer to your view? & $\begin{array}{l}0 \text { Government should cut taxes a lot ... } 10 \text { government should increase taxes a } \\
\text { lot. }\end{array}$ \\
\hline WTP Medical care & $\begin{array}{l}\text { Wait times for many medical procedures (such as cataract surgery and hip and knee } \\
\text { replacements) are currently longer than recommended by doctors. If tax dollars were } \\
\text { guaranteed to go to these priority areas and to reduce wait times, would you support this } \\
\text { policy if it were to cost X? }\end{array}$ & $£ 2000, £ 1500, £ 1000, £ 500$ and $£ 100$ \\
\hline WTP Tuition & $\begin{array}{l}\text { Some politicians and policy groups propose making the first four years of university free } \\
\text { for all qualified students. This will result in greater accessibility to university education. } \\
\text { Would you support the elimination of tuition fees if it cost you X more per year in taxes? }\end{array}$ & $£ 100, £ 250, £ 500, £ 1000$ and $f 2000$. \\
\hline Party ID & $\begin{array}{l}\text { Generally speaking, do you think of yourself as Labour, Conservative, Liberal Democrat or } \\
\text { what? }\end{array}$ & $\begin{array}{l}\text { Labour, Conservative, Liberal Democrat, Scottish National Party (SNP), Plaid } \\
\text { Cymru, Green Party, United Kingdom Independence Party (UKIP), British } \\
\text { National Party (BNP), Other, None, Don't know }\end{array}$ \\
\hline Strength of partisanship & Would you call yourself a very strong party supporter, fairly strong or not very strong? & $\begin{array}{l}\text { 1. Very strong party supporter } 2 \text {. Fairly strong party supporter } 3 \text {. Not very } \\
\text { strong party supporter } 4 \text {. Don't know }\end{array}$ \\
\hline $\begin{array}{l}\text { Dictator game question } \\
\text { (anonymous) }\end{array}$ & $\begin{array}{l}\text { At the end of this study, we'll be conducting a random draw for } f 100 \text {. All respondents } \\
\text { who complete the study will be eligible. If you win, you'll have the chance to share your } \\
\text { prize with another completely anonymous individual who also completed the survey. } \\
\text { Please keep in mind that whether you share your prize will have no effect on your chances } \\
\text { of winning! Also, you will never know the identity of the person with whom you share the } \\
\text { prize and they'll never know your identity. Finally, remember that you don't have to share } \\
\text { anything if you don't wish. If you won the prize, how much would you give to a completely } \\
\text { anonymous individual? }\end{array}$ & $\begin{array}{l}\text { If you won the prize, how much would you give to a completely anonymous } \\
\text { individual? }\end{array}$ \\
\hline
\end{tabular}


Table A5. United States

\begin{tabular}{|c|c|c|}
\hline & Question & Response alternatives \\
\hline Right-wing & $\begin{array}{l}\text { In political matters, people talk of "the left" and "the right." How would you place your views on this } \\
\text { scale, generally speaking? }\end{array}$ & 1. Left ... 10. Right. \\
\hline Increase taxes & $\begin{array}{l}\text { Now please indicate your views on various issues. How would you place your views on this scale? } 1 \\
\text { means you agree completely with the statement on the left; } 10 \text { means you agree completely with the } \\
\text { statement on the right; and if your views fall somewhere in between, you can choose any number in } \\
\text { between. }\end{array}$ & $\begin{array}{l}\text { 1. Government should cut taxes a lot and spend much less on } \\
\text { health and social services. ... 10. Government should increase } \\
\text { taxes a lot and spend much more on health and social services. }\end{array}$ \\
\hline Increase income inequality & $\begin{array}{l}\text { Now please indicate your views on various issues. How would you place your views on this scale? } 1 \\
\text { means you agree completely with the statement on the left; } 10 \text { means you agree completely with the } \\
\text { statement on the right; and if your views fall somewhere in between, you can choose any number in } \\
\text { between. }\end{array}$ & $\begin{array}{l}\text { 1. Income should be made more equal. ... 10. We need larger } \\
\text { income differences as incentives for individual effort. }\end{array}$ \\
\hline Government less responsibility & $\begin{array}{l}\text { Now please indicate your views on various issues. How would you place your views on this scale? } 1 \\
\text { means you agree completely with the statement on the left; } 10 \text { means you agree completely with the } \\
\text { statement on the right; and if your views fall somewhere in between, you can choose any number in } \\
\text { between. }\end{array}$ & $\begin{array}{l}1 \text { The government should take more responsibility to ensure that } \\
\text { everyone is provided for. ... } 10 \text { People should take more } \\
\text { responsibility to provide for themselves. }\end{array}$ \\
\hline WTP Climate & $\begin{array}{l}\text { One proposed solution to fight climate change and decrease air pollution is to impose carbon taxes. } \\
\text { Supporters of these environmental policies say such taxes would result in cleaner air and better health } \\
\text { for everyone. Would you support carbon taxes if you knew it would cost you... }\end{array}$ & $\begin{array}{l}\$ 2000 / 1500 / 1000 / 500 / 100 \text { more per year to heat your home, } \\
\text { ride the bus, and drive a car? }\end{array}$ \\
\hline WTP Medical care & $\begin{array}{l}\text { Wait times for many medical procedures (such as cataract surgery and hip and knee replacements) are } \\
\text { currently longer than recommended by doctors. If tax dollars were guaranteed to go to these priority } \\
\text { areas and to reduce wait times, would you be willing to pay... }\end{array}$ & $\$ 2000 / 1500 / 1000 / 500 / 100$ more per year in taxes? \\
\hline WTP Tuition & $\begin{array}{l}\text { Some politicians and policy groups propose making the first four years of university free for all qualified } \\
\text { students, just like high school. This will result in greater accessibility to university education. Would you } \\
\text { support the elimination of tuition fees if it cost you ... }\end{array}$ & $\$ 2000 / 1500 / 1000 / 500 / 100$ more per year in taxes? \\
\hline Party ID & $\begin{array}{l}\text { Generally speaking, do you usually think of yourself as a Republican, a Democrat, an independent, or } \\
\text { what? }\end{array}$ & 1. Republican 2. Democrat 3. Independent 4. Other \\
\hline Strength of partisanship & $\begin{array}{l}\text { If Republican/Democrat: Do you think of yourself as a strong Republican/Democrat or not very strong } \\
\text { Republican/Democrat? } \\
\text { If Independent: Do you think of yourself as closer to the Republican Party or to the Democratic Party? }\end{array}$ & $\begin{array}{l}\text { 1. Strong Republican/Democrat/Independent } \\
\text { 2. Not very strong Republican/Democrat/Independent }\end{array}$ \\
\hline $\begin{array}{l}\text { Dictator game question } \\
\text { (anonymous; Partisan / ideology } \\
\text { treatment in brackets.) }\end{array}$ & $\begin{array}{l}\text { Below, you will see two boxes. In the first box, enter how much of a } \$ 100 \text { prize you would keep if you } \\
\text { won the prize drawing. In the other box, indicate how much you'd like to give away to an anonymous } \\
\text { individual who will also be randomly chosen. You know nothing about this anonymous individual [except } \\
\text { that] [they support the Republican Party, they support the Democratic Party, they are a conservative, } \\
\text { they are a liberal]. } \\
\text { You must choose how to divide the } \$ 100 \text { between yourself and the anonymous individual. You may keep } \\
\text { all, none, or some of the money - the decision is up to you and will be completely anonymous. The total } \\
\text { of the two boxes must add up to } \$ 100 \text {. Once you have made your decision, please hit next. }\end{array}$ & 0 to $\$ 100$. \\
\hline
\end{tabular}


Table A6. Partisanship and ordering of choices in Sweden

\begin{tabular}{lcc}
\hline Right-wing bloc & -1.532 & -1.622 \\
Same & $(1.708)$ & $(2.044)$ \\
& $7.756^{* * *}$ & $8.966^{* * *}$ \\
First partisan choice & $(1.663)$ & $(1.931)$ \\
& $-4.664^{* *}$ & $-5.890^{* *}$ \\
First partisan choice*Right wing bloc & $(2.127)$ & $2.508)$ \\
& 0.967 & 1.449 \\
First partisan choice*Same & $(1.593)$ & $(1.931)$ \\
& $5.463^{*}$ & $6.245^{*}$ \\
$N /$ Individuals & $(2.971)$ & $(3.412)$ \\
& $1452 / 726$ & $1026 / 513$ \\
\hline
\end{tabular}

The dependent variable is the donated sum in a dictator game. All coefficients expressed in percent of maximum donation. Heteroskedasticity-robust standard errors clustered at the individual level are reported in parentheses. One star denotes statistical significance at the 10 percent level in a two-sided test; two stars denote significance at the 5 percent level and one star at the 1 percent level. All regressions include the same set of controls as in Table 2 for Sweden. The "Same" variable for Sweden is calculated based upon consistency between the party affiliation of the dictator and the response to the continuous left-right question of the respondent. Respondents who identify with "Sverigedemokraterna" are excluded. 
Table A7. Generosity and Partisanship in Swedish Pilot

\begin{tabular}{|c|c|c|c|c|c|c|}
\hline & 1 & 2 & 3 & 4 & 5 & 6 \\
\hline \multirow[t]{2}{*}{ Right-wing } & $-19.80 * * *$ & $-18.70 * * *$ & $-13.68 * * *$ & $-17.24 * * *$ & $-17.36^{* *}$ & $-15.80 * *$ \\
\hline & (3.77) & (3.88) & (4.11) & (6.59) & $(6.96)$ & $(6.78)$ \\
\hline \multirow[t]{2}{*}{ Same } & 2.87 & 1.63 & 2.24 & 4.76 & 2.62 & 0.35 \\
\hline & $(4.00)$ & $(4.15)$ & (4.11) & (5.56) & $(5.70)$ & $(6.37)$ \\
\hline \multirow[t]{2}{*}{ Right-wing*Same } & & & & -4.12 & -2.15 & 4.16 \\
\hline & & & & $(8.01)$ & $(8.34)$ & (9.11) \\
\hline$N$ & 184 & 174 & 174 & 184 & 174 & 174 \\
\hline$R^{2}$ & 0.139 & 0.126 & 0.191 & 0.141 & 0.126 & 0.193 \\
\hline Control variables & No & No & Yes & No & No & Yes \\
\hline Sample restriction & No & Controls observed & Controls observed & No & Controls observed & Controls observed \\
\hline
\end{tabular}

